\title{
METRIC CHARACTERISTICS OF URSID CHEEK TEETH FROM ZA HÁJOVNOU CAVE (JAVOŘÍČKO KARST, THE CZECH REPUBLIC) AND ITS TAXONOMICAL IMPLICATION
}

\author{
JAN WAGNER \\ National Museum, Department of Palaeontology, Václavské náměstí 68, 11579 Prague 1, the Czech Republic; e-mail: \\ jan_wagner@nm.cz \\ Institute of Geology AS CR, v. v. i., Rozvojová 269, 16500 Prague 6, the Czech Republic; e-mail: wagnerj@gli.cas.cz
}

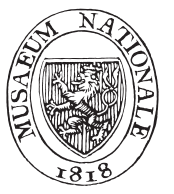

Wagner, J. (2014): Metric characteristics of ursid cheek teeth from Za Hájovnou Cave (Javoříčko Karst, the Czech Republic) and its taxonomical implication. - Acta Mus. Nat. Pragae, Ser. B, Hist. Nat., 70(1-2): 71-90, Praha. ISSN 1804-6479.

Abstract. Teeth material of bears from Za Hájovnou Cave was analysed in detail and determined as Ursus cf. deningeri from the Middle Pleistocene sample and as Ursus gr. spelaeus from the Late Pleistocene sample. On the basis of their metric characteristics, the Middle Pleistocene bears are at the evolutionary level of Early/Middle Toringian representatives of the spelaeoid lineage. No trends between MIS 11 and MIS 9 taxonomical units were found.

- Ursus deningeri, Middle Pleistocene, MIS 11, MIS 9, Toringian, Central Europe

Received July 25, 2014

Issued October, 2014

\section{Introduction}

In 2001, a team of specialists under the leadership of Prof. R. Musil (Faculty of Sciences, Masaryk University, Brno) in cooperation with the Moravian Museum (Brno) and Czech Speleological Society (ZO 7-03 Javoříčko) started excavations of the Za Hájovnou Cave (Javoříčko Karst, the Czech Republic). The results of the first phase of excavations (2001-2004) were published in volume 8 of the Př́rodovědné Studie Muzea Prostějovska journal (bear remains were discussed by Musil 2005b, Nývltová Fišáková 2005, Sabol 2005a, and Wagner 2005). After publication of this volume, excavations continued and some additional papers, describing material from this locality, were published (Ábelová 2005, Sabol 2005b, Doláková 2007, Ivanov 2007, Nývltová-Fišáková 2007, Vöröš 2013), including new Th/U dating of several profiles (Lundberg et al. 2014).

Based on the published data (see references above and respective papers in this volume), most of the fossil material is represented by ursid remains from the Middle Pleistocene (MIS 9 and probably MIS 11), at least partly (MIS 9 specimens) reflecting the former usage of this cave as a bear cave. In addition, Late Pleistocene ursids were also recorded in one part of this cave.

The previous paper dealing with bear taxonomy (Wagner 2005) was focused on the specimens later assigned to MIS 9 unit and to the Chodba naděje (= Corridor of Hope) unit for which the exact stratigraphic position is unknown (but assumed to be Middle Pleistocene interglacial; Musil 2005a). The main goal of that paper was to determine ursids at the species level (detailed stratigraphy for the fossiliferous layers was unknown at that time). These bears (from both the above mentioned units) were determined as Ursus cf. deningeri, with the exception of two small specimens determined as Ursus sp. After 2004, the stratigraphic position of several sites within the cave was specified (Lundberg et al. 2014) and other new ursid material was excavated (mostly tentatively assigned to MIS 11). Thus, the aim of this paper is to provide metric characteristics of the new material and compare metric characteristics of bears from different stratigraphic units in Za Hájovnou Cave and with those from selected early Middle Pleistocene localities in Central Europe.

\section{Material and methods}

The present study is based on the ursid material from $\mathrm{Za}$ Hájovnou Cave collected between the years 2001-2012 (with the exception of the 2008 collection which was still under preparation during writing of this paper). All the permanent ursid cheek teeth of known stratigraphic position or originating from the Chodba naděje were included in the study (the only exceptions are three small specimens - see below for details). All the studied material from Za Hájovnou Cave is deposited in the Moravian Museum (= Moravské zemské muzeum, Brno, the Czech Republic).

The studied material was divided into 5 units, mostly according to stratigraphic position (following Lundberg et al. 2014): LP (= Late Pleistocene), MIS 9, MIS 10, MIS 11, and the Chodba naděje. These units include specimens from several sites within the cave (see Sabol (2014) for parallelization between fossiliferous sites terminology in Lundberg et al. (2014) and the names on the museum labels and their subsequent assignation to appropriate MIS stages). The material from the Chodba naděje was included despite 
lack of precise stratigraphic determination because it represents a rather large and homogenous set of teeth. Other material without accurate stratigraphic position was not included. The units LP and MIS 10 are represented by only a few teeth. I excluded two small teeth (No. 162, 163), determined by Wagner (2005) as Ursus sp., from MIS 9 unit and one similarly small tooth (m2 sin., No. 2009/8) from MIS 11 unit. The taxonomical status of these teeth is unclear and although they possibly represent only the extreme morphotypes of $U$. deningeri, I prefer not to include them in the present analyses.

I used the numbering (simple numbers) and measurements from Wagner (2005) for the specimens collected between 2001 and 2004. Specimens collected after 2004 were measured in 2013 and the museum inventory numbers (Ok \#\#\#\#) were used where available. Where museum numbers were not yet available, I marked each tooth with the year of collection, slashed with a serial number (the order in which I measured the particular tooth), e.g. 2009/25.

The following material was used for comparative purposes (a) Late Biharian (LB): Cave C 718, Koněprusy Caves (both the Czech Republic), Kozi Grzbiet (Poland), and Kövesvárad (Hungary; only Kövesvárad sp. A sensu Wagner and Čermák 2012) and (b) Early Toringian (ET): Mauer, Mosbach 2 (both Germany), Hundsheim (Austria), and Tarkő (Hungary). The Late Biharian localities represent MIS 17, in the case of the Koněprusy Caves it is not certain if this locality represents MIS 17 or 19 (see references in Wagner and Čermák 2012 for details). The Early Toringian (preElsterian) localities represent MIS 15 (Mauer and most probably Tarkö) and MIS 15 or 13 (Mosbach 2 and Hundsheim; Mosbach 2 probably represents a longer period) (Jánossy 1976, Koenigswald and Heinrich 1999, Maul et al. 2000, Maul and Heinrich 2007, Kahlke et al. 2011).

All the material used for comparison was studied and measured by the author. The same data as in Wagner (2003, 2005) are used for Mosbach 2. All the other material was measured or re-measured after 2005, so the data for Hundsheim, Cave C 718, and Koněprusy Caves partially differ from those used by Wagner $(2003,2005)$. The data from the Late Biharian localities are the same, with the exception of several additional measurements (e.g. Pa and Me height for M1), as used by Wagner and Čermák (2012). The comparative material studied was from the following collections: the National Museum in Prague (the Czech Republic; Cave C 718, Koněprusy Caves), the Hungarian Natural History Museum (Hungary; Kövesvárad, Tarkő), the Institute of Systematics and Evolution of Animals PAN (Poland; Kozi Grzbiet), Staatliches Museum für Naturkunde Karlsruhe (Germany; Mauer), Naturhistorisches Museum Mainz (Germany; Mosbach 2), and Institut für Paläontologie - Universität Wien (Austria; Hundsheim).

The measurements were taken with the aid of engineering callipers with an accuracy of $0.1 \mathrm{~mm}$. The teeth measurements were defined according to Rode (1935). An exception is the buccal length of the anterior and posterior lobe of M1 which was measured from the $\mathrm{Me} / \mathrm{Pa}$ boundary to the end of the parastyle and metastyle respectively, with the tips of the calliper jaws touching the landmarks (in contrary to Rode (1935) where this parameter is taken parallel to the tooth axis). The lingual length of P4 was defined according to
Baryshnikov (1998, 2007; character No. 4 for P4). The terminology and abbreviations for teeth morphology structures were adopted from Rabeder (1983, 1989, 1999). The term $\mathrm{x}$-conid/cone refers strictly to the cusp itself, while the term $\mathrm{x}$-conid/cone-complex denotes the cusp with its secondary structures (small cusps, swellings etc.). For length characteristics of End-complex in $\mathrm{m} 1$ and $\mathrm{m} 2$, I used the comparison of End 1/2-complex lengths (following Wagner and Čermák 2012) contrary to Wagner (2005), where just the End 1/2 length is used. For M1, length of paracone/ metacone-complex (parastyle and metastyle not included) represents the same character as length of paracone/metacone in Wagner and Čermák (2012).

Capital and lowercase letters $\mathrm{P} / \mathrm{p}$ (premolars) and $\mathrm{M} / \mathrm{m}$ (molars), refer to upper and lower permanent teeth, respectively.

The definition and subdivision of the Quaternary period follow Gibbard and Cohen (2008) and Gibbard and Head $(2009 a, b)$. The definition and subdivision of the Mammal Ages (Biharian and Toringian) follow Fejfar and Heinrich (1983, 1990) and Fejfar et al. (1998). In the following text the Early Toringian refers to pre-Elsterian Toringian faunas, and similarly the Middle Toringian, the post-Elsterian Middle Pleistocene faunas.

\section{Results}

Only metric characters were studied in the present analysis (see Appendix 1, Tab. A1-A7 for measurements of particular teeth excavated after 2004 from Za Hájovnou Cave). The results are therefore preliminary. Additional detailed morphological analysis is necessary for a definitive evaluation of taxonomical position and evolutionary niveau of the studied ursids. Unfortunately, there is no scheme for morphological characters/changes easily applicable for (later) $U$. deningeri and it will be necessary to develop one in the future.

Another problem is connected with the forming of taxonomical units. As mentioned above, MIS 9 unit includes all specimens from different sites in the cave assigned by Lundberg et al. (2014) to MIS 9. But there is no certainty that all of the material really represents one period/population within MIS 9. Similarly, MIS 11 unit is formed by ursid material from Propástka 1 and 2 (= Abyss I and II), e.g. layer 5-6 in profile ZH P-8/9 sensu Lundberg et al. (2014). But these two layers represent more than $10 \mathrm{~m}$ of sediment and there are no indications, at present, of how long a period it represents. The assignation to MIS 11 (the assignation to interglacial is based on the palynological record (Doláková 2014)) is only conditional without any direct evidence (Lundberg et al. 2014). According to Lundberg et al. (2014) it seems probably that these layers represent older interglacial than the main cave infilling from MIS 9, most probably MIS 11. Despite these facts, I consider forming of these taxonomical units as necessary with respect to evaluation of interpopulation comparison and trends in phenotypic changes. Moreover, the character of comparative units is also similar and, at least in several instances (e.g. Mosbach 2), material from one locality covers a longer period.

All the material included in this study can be assigned to the spelaeoid lineage. No unambiguous representatives 
Table 1. Metric characteristics and indexes for $\mathbf{P} 4$ from studied and comparative taxonomical units. Measurements in mm, indexes in $\%$. LINL - lingual length; MAXL - maximal length; MAXW - maximal width; WCON - width of constriction.

\begin{tabular}{|c|c|c|c|c|c|c|c|}
\hline \multicolumn{2}{|l|}{ P4 } & $\frac{1}{2}$ & $\frac{\sum}{\sum}$ & $\begin{array}{l}z \\
0 \\
0 \\
z\end{array}$ & $\underset{\mathrm{Z}}{\mathrm{Z}}$ & $\sum_{\frac{3}{3}}^{\frac{\partial}{x}}$ & 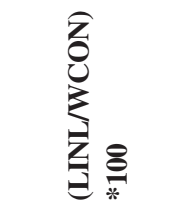 \\
\hline \multirow{3}{*}{ Za Hájovnou - Late Pleistocene } & $\mathrm{n}$ & - & 1 & - & 1 & - & - \\
\hline & avr. & - & 14.0 & - & 17.0 & - & - \\
\hline & min.-max. & - & - & - & - & - & - \\
\hline \multirow{3}{*}{ Za Hájovnou - MIS 9} & $\mathrm{n}$ & 7 & 9 & 7 & 8 & 7 & 7 \\
\hline & avr. & 18.16 & 13.38 & 11.00 & 14.25 & 77.69 & 131.37 \\
\hline & $\min .-\max$. & $17.0-19.1$ & $11.8-14.9$ & $9.9-11.8$ & $12.8-15.8$ & $70.33-88.27$ & $126.73-142.34$ \\
\hline \multirow{3}{*}{ Za Hájovnou - MIS 11} & $\mathrm{n}$ & 10 & 10 & 9 & 9 & 9 & 9 \\
\hline & avr. & 18.23 & 12.91 & 11.31 & 14.34 & 79.68 & 126.87 \\
\hline & $\min .-\max$. & $16.4-20.0$ & $12.2-13.7$ & $10.4-12.3$ & $12.3-15.2$ & $73.21-90.24$ & $118.27-133.64$ \\
\hline \multirow{3}{*}{ Za Hájovnou - Chodba naděje } & $\mathrm{n}$ & 5 & 5 & 2 & 5 & 5 & 2 \\
\hline & avr. & 18.72 & 13.42 & 10.55 & 14.62 & 77.91 & 122.30 \\
\hline & $\min .-\max$. & $16.3-20.6$ & $11.7-14.6$ & $10.1-11.0$ & $12.4-16.6$ & $75.28-81.77$ & $121.82-122.77$ \\
\hline \multirow{3}{*}{ ET - Mosbach 2} & $\mathrm{n}$ & 18 & 16 & 15 & 14 & 14 & 14 \\
\hline & avr. & 18.29 & 12.52 & 10.89 & 13.43 & 74.10 & 124.38 \\
\hline & $\min .-\max$. & $15.4-20.6$ & $10.8-14.7$ & $9.1-12.3$ & $10.5-17.2$ & $56.76-85.15$ & $100.00-146.53$ \\
\hline \multirow{3}{*}{ ET - Hundsheim } & $\mathrm{n}$ & 6 & 6 & 7 & 7 & 6 & 7 \\
\hline & avr. & 19.28 & 13.40 & 11.50 & 14.73 & 76.72 & 127.94 \\
\hline & $\min .-\max$. & $17.5-21.8$ & $12.6-14.0$ & $10.5-12.6$ & $11.4-17.0$ & $64.04-82.72$ & $105.56-141.07$ \\
\hline \multirow{3}{*}{ ET - Mauer } & $\mathrm{n}$ & 1 & 1 & 1 & 1 & 1 & 1 \\
\hline & avr. & 20.3 & 14.0 & 12.5 & 16.9 & 83.25 & 135.20 \\
\hline & $\min .-\max$. & - & - & - & - & - & - \\
\hline \multirow{3}{*}{ ET - Tarkő } & $\mathrm{n}$ & 3 & 3 & 3 & 2 & 2 & 2 \\
\hline & avr. & 18.67 & 13.73 & 12.00 & 15.70 & 85.46 & 129.89 \\
\hline & $\min .-\max$. & $16.9-19.7$ & $12.0-15.4$ & $10.9-13.2$ & $13.7-17.7$ & $81.07-89.85$ & $125.69-134.09$ \\
\hline \multirow{3}{*}{ LB - C718 } & $\mathrm{n}$ & 7 & 8 & 8 & 8 & 7 & 8 \\
\hline & avr. & 19.93 & 14.05 & 12.38 & 15.94 & 78.68 & 128.86 \\
\hline & min.-max. & $18.8-20.9$ & $13.4-15.2$ & $11.4-14.0$ & $14.5-17.8$ & $72.86-83.08$ & $122.88-135.09$ \\
\hline \multirow{3}{*}{ LB - Koněprusy Caves } & $\mathrm{n}$ & 20 & 21 & 21 & 21 & 20 & 21 \\
\hline & avr. & 18.04 & 12.86 & 11.24 & 14.45 & 79.85 & 128.52 \\
\hline & min.-max. & $15.9-20.2$ & $11.3-14.3$ & $10.2-12.3$ & $12.8-16.5$ & $71.43-86.78$ & $120.00-142.24$ \\
\hline \multirow{3}{*}{ LB - Kozi Grzbiet } & $\mathrm{n}$ & 9 & 8 & 9 & 9 & 9 & 9 \\
\hline & avr. & 18.14 & 12.59 & 11.12 & 13.78 & 75.75 & 123.91 \\
\hline & $\min .-\max$. & $16.4-19.5$ & $10.9-14.5$ & $9.5-13.5$ & $11.6-16.9$ & $70.73-86.67$ & $115.00-130.28$ \\
\hline
\end{tabular}

of $U$. arctos or $U$. thibetanus were recorded. The Late Pleistocene finds are determined as Ursus gr. spelaeus. But this determination is rather formal with the respect to the stratigraphic position of specimens. The sample is too small and the overlap between $U$. spelaeus and later $U$. deningeri is substantial, so for most of the specimens it is not possible to identify any discriminative characters. There are no additional cheek teeth from the LP unit in contrast to Wagner (2005). Most of the Middle Pleistocene teeth excavated after 2004 belong to MIS 11 unit, only a few specimens represent MIS 9 or Chodba naděje units. All the determinable ursids cheek teeth from Middle Pleistocene layers are assigned to Ursus $\mathrm{cf}$. deningeri. From a metrical (as well as morphological) viewpoint, they represent classical spelaeoid bears of earlier evolutionary stages. In the following part I present the metrical characteristic of bears from Za Hájovnou Cave with respect to possible phenotypical changes through the Middle Pleistocene.
P4 sup. (Tab. 1). The Late Pleistocene taxa (Ursus gr. spelaeus) are characterized by an advanced molarisation correlated with an increase in maximal length (Rabeder 1983, 1989). But in the studied samples from MIS 17 to MIS 9, there are no apparent metrical changes in this respect. The values of $\mathrm{Za}$ Hájovnou Cave units are within a variation of both Late Biharian and Early Toringian samples. The average values from the studied units are also within the average value limits of comparative samples. The Chodba naděje unit shows no prevalent affinity to either MIS 11 unit or MIS 9, unit.

M1 sup. (Tab. 2, 3). This tooth is traditionally used for differentiation between U. spelaeus and U. arctos (Rode 1935, Kurtén 1955, 1959). Among the spelaeoid (i.e. typical for Ursus gr. spelaeus) characters can be included: e.g., increase of size, increase percentage of specimens with (a) paracone higher than metacone, (b) paracone longer than metacone, or (c) anterior lobe as wide as or wider than the posterior one (op. cit.; see also Wagner (2005) for an overview). 
If we compare the average maximal length values, our samples can be split more or less into two main groups - the Toringian group with slightly higher values and the Biharian with slightly lower values (if we use median instead of average, this tendency becomes less apparent). In this character, pre- and post-Elsterian units do not show significant differences, with the exception of the Mosbach unit in which the average value is even lower than those in the Biharian samples (we can also see in some other teeth that those in the Mosbach sample are rather small in comparison to other Toringian units). But there is a large overlap among particular taxonomical units (moreover, the units in which only a few teeth were found do not provide relevant average values). The relative width of the posterior lobe (with respect to maximal length) also shows a similar split, with some tendency towards a relatively broader posterior lobe in the Biharian units (in Koněprusy Caves unit it is less apparent). Frequency of specimens with a mesial lobe wider than the posterior lobe (a spelaeoid character) provides interesting values. Bears in Za Hájovnou Cave are less spelaeoid in this character than Early Toringian bears and at the same or a lower level than Late Biharian specimens. There are somewhat different values for this character in Late Biharian bears in Wagner (2005) compared to the present study. These differences are mostly caused by partly different values obtained during re-measuring of our samples

Table 2. Metric characteristics and indexes for M1 from studied and comparative taxonomical units. Measurements in mm, indexes in \%. HME - metacone height; HPA - paracone height; LANT - length of anterior lobe; LMEC - metacone-complex length; LPAC paracone-complex length; LPOST - length of posterior lobe; MAXL - maximal length; RELWCON = $(\mathrm{WCON} /((\mathrm{WANT}+\mathrm{WPOST}) / 2)) * 100$; WANT - width of anterior lobe (across Pa); WCON - width of constriction; WPOST - width of posterior lobe (across Me) continues on p. 75.

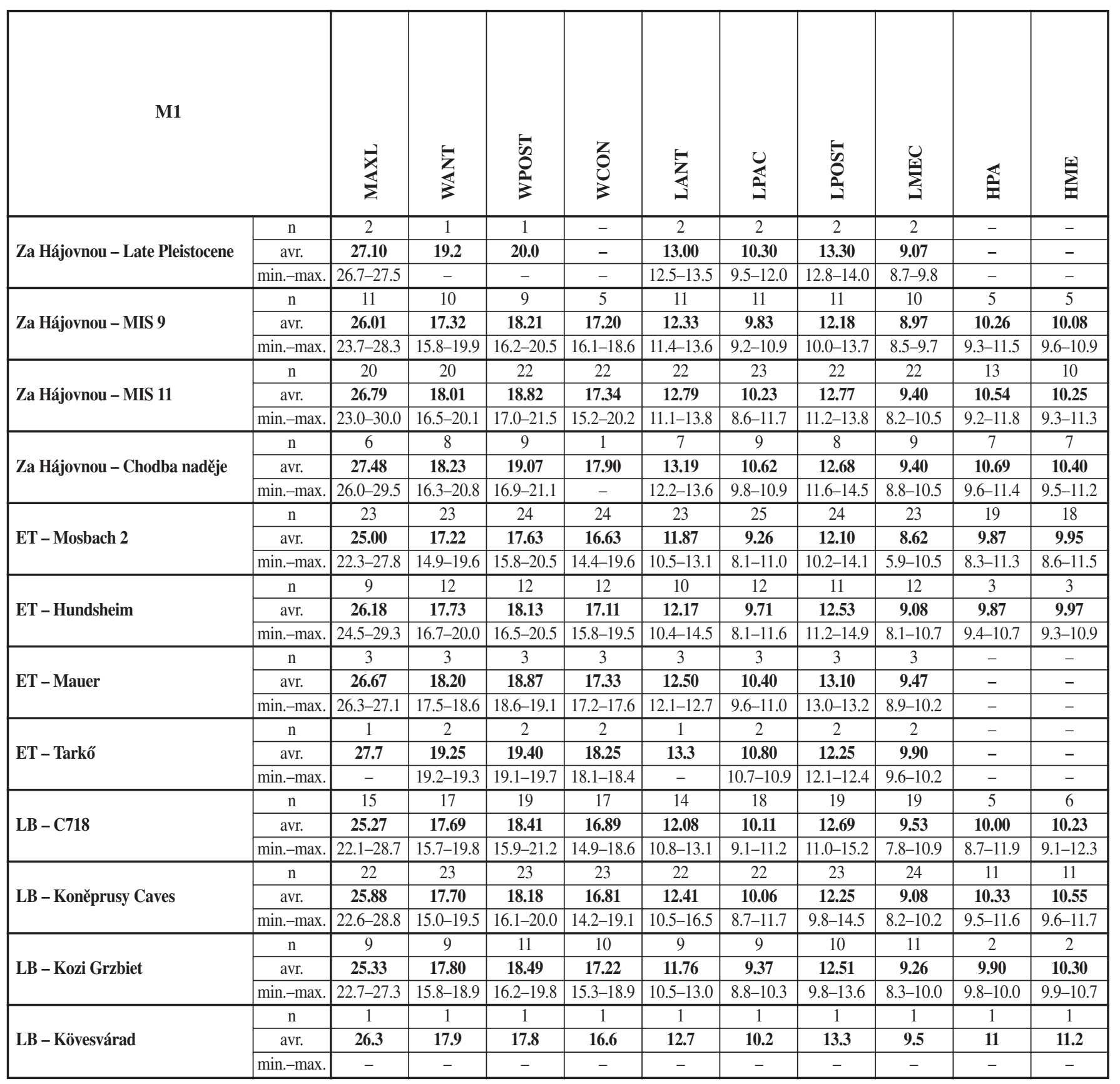


(moreover, the Late Biharian unit in Wagner (2005) also included OIS 19 specimens from Chlum I and IV). On the other hand, the height and length ratios for $\mathrm{Pa}$ and $\mathrm{Me}$ are dominantly spelaeoid in Za Hájovnou Cave bears. There seems to be a trend from Late Biharian to Middle Toringian (post-Elsterian) units in the percentage increase of teeth with higher $\mathrm{Pa}$ than Me. Unfortunately, the number of teeth suitable for study of this particular character (unworn or only slightly worn) is limited in the studied samples. Considering the $\mathrm{Pa} / \mathrm{Me}$ length ratio, the differences among units from different stratigraphic levels are much less apparent.

M2 sup. (Tab. 4). We can see some trends from Late Biharian to Late Toringian units in several characters. In general, teeth from Late Biharian units are on average smaller, Early and Middle Toringian somewhat larger, and from Late Toringian (LP unit) are the largest. The exception is material from Mosbach 2, which is relatively small (on the level of Biharian units) and Koněprusy Caves unit material which is on average larger than that from the rest of the Late Biharian units (and, in some characters, on the level of the Toringian units). These trends are most clearly documented in the increase in maximal length and $\mathrm{Pa}$ and $\mathrm{Pa}$-complex length. LP unit stands alone with respect to maximal length. There are no apparent differences between Early Toringian units (with the exception of Mosbach 2) and those from Za Hájovnou Cave. In the above mentioned characters, MIS 9 unit and Chodba naděje unit are more similar to each other than to MIS 11 unit and their average values are higher than those from MIS 11 unit.

p4 inf. (Tab. 5). There are no features of p4 inf. which could distinguish the units with respect to stratigraphic level. Surprisingly, the Late Biharian as well as Mosbach 2 samples have a relatively longer maximal length. There is no pattern within Za Hájovnou Cave units.

Table 2. continuation.

\begin{tabular}{|c|c|c|c|c|c|c|c|c|c|}
\hline \multicolumn{2}{|l|}{ M1 } & 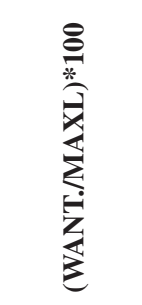 & 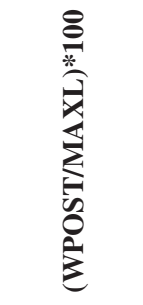 & 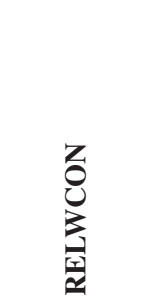 & & 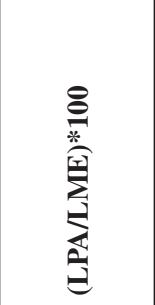 & 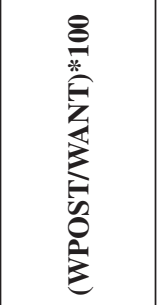 & 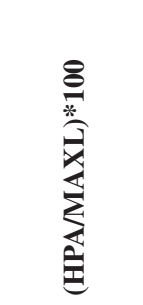 & 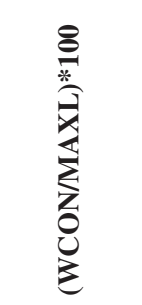 \\
\hline \multirow{3}{*}{ Za Hájovnou - Late Pleistocene } & $\mathrm{n}$ & 1 & 1 & - & - & 2 & 1 & - & - \\
\hline & avr. & 71.27 & 75.27 & - & - & 104.22 & 105.61 & - & - \\
\hline & min.-max. & - & - & - & - & 96.94-111.49 & - & - & - \\
\hline \multirow{3}{*}{ Za Hájovnou - MIS 9} & $\mathrm{n}$ & 10 & 9 & 5 & 5 & 10 & 9 & 5 & 5 \\
\hline & avr. & 66.57 & 70.57 & 95.43 & 101.68 & 109.47 & \begin{tabular}{|l|}
104.36 \\
\end{tabular} & 39.26 & 67.74 \\
\hline & min.-max. & $57.24-70.57$ & $64.03-74.21$ & $92.07-98.67$ & $96.88-105.50$ & $102.22-118.48$ & 101.17-110.00 & $38.52-40.78$ & $65.45-69.66$ \\
\hline \multirow{3}{*}{ Za Hájovnou - MIS 11} & $\mathrm{n}$ & 18 & 19 & 19 & 10 & 22 & 19 & 12 & 19 \\
\hline & avr. & 67.97 & 70.54 & 94.20 & 101.85 & 109.13 & 104.35 & 39.76 & 65.53 \\
\hline & min.-max. & $62.18-71.92$ & $67.27-75.77$ & $90.75-97.63$ & $98.06-105.26$ & $93.48-123.16$ & 98.99-112.28 & $36.07-43.49$ & $61.69-68.85$ \\
\hline \multirow{3}{*}{ Za Hájovnou - Chodba naděje } & $\mathrm{n}$ & 5 & 5 & 1 & 6 & 8 & 7 & 5 & - \\
\hline & \begin{tabular}{|l|} 
avr. \\
\end{tabular} & 64.86 & 68.77 & 97.02 & 102.15 & \begin{tabular}{|l|}
113.66 \\
\end{tabular} & \begin{tabular}{|l|}
103.23 \\
\end{tabular} & 39.08 & - \\
\hline & min.-max. & $61.98-69.62$ & $63.81-73.12$ & - & $99.07-107.77$ & $101.90-122.47$ & 99.04-111.48 & $36.27-40.77$ & - \\
\hline \multirow{3}{*}{ ET - Mosbach 2} & $\mathrm{n}$ & 22 & 22 & 23 & 17 & 23 & 23 & 19 & 22 \\
\hline & avr. & 68.74 & 70.01 & 95.12 & 99.91 & 107.93 & 101.76 & 39.36 & 65.87 \\
\hline & min.-max. & $62.26-75.59$ & $64.20-74.35$ & $88.83-99.42$ & $88.60-105.61$ & 94.29-138.98 & 93.23-106.04 & $35.17-44.81$ & $60.31-74.35$ \\
\hline \multirow{3}{*}{ ET - Hundsheim } & $\mathrm{n}$ & 9 & 9 & 12 & 2 & 12 & 12 & 3 & 9 \\
\hline & avr. & 68.26 & 70.11 & 95.42 & 98.05 & 106.89 & \begin{tabular}{|l|}
102.30 \\
\end{tabular} & 39.91 & 66.13 \\
\hline & min.-max. & $66.55-71.27$ & $66.53-73.26$ & $92.56-98.08$ & 97.94-98.17 & 93.07-115.38 & 96.34-108.62 & $37.45-43.67$ & $63.71-68.85$ \\
\hline \multirow{3}{*}{ ET - Mauer } & $\mathrm{n}$ & 3 & 3 & 3 & - & 3 & 3 & - & 3 \\
\hline & avr. & 68.28 & 70.76 & 93.53 & - & 109.90 & \begin{tabular}{|l|}
103.75 \\
\end{tabular} & - & 65.01 \\
\hline & min.-max. & $64.58-70.72$ & $69.74-71.80$ & $92.47-94.51$ & - & $107.84-113.98$ & $100.00-108.00$ & - & $63.47-66.17$ \\
\hline \multirow{3}{*}{ ET - Tarkố } & $\begin{array}{l}\mathrm{n} \\
\end{array}$ & 1 & 1 & 2 & - & 2 & 2 & - & 1 \\
\hline & avr. & 69.31 & 71.12 & 94.44 & - & 109.22 & 100.78 & - & 66.43 \\
\hline & min.-max. & - & - & $94.27-94.60$ & - & $104.90-113.54$ & 98.96-102.60 & - & - \\
\hline \multirow{3}{*}{ LB - C718 } & $\mathrm{n}$ & 15 & 15 & 15 & 5 & 18 & 17 & 5 & 13 \\
\hline & avr. & 69.37 & 72.03 & 93.95 & 96.30 & 106.32 & 103.53 & 39.95 & 66.43 \\
\hline & min.-max. & $65.07-75.50$ & $67.93-77.38$ & $90.76-98.53$ & 94.06-98.08 & $97.85-119.23$ & 95.65-108.90 & $36.47-42.99$ & $62.87-71.49$ \\
\hline \multirow{3}{*}{ LB - Koněprusy Caves } & $\mathrm{n}$ & 21 & 21 & 23 & 11 & 22 & 23 & 11 & 21 \\
\hline & avr. & 68.97 & 70.83 & 93.69 & 97.87 & 110.58 & 102.77 & 39.63 & 65.64 \\
\hline & min.-max. & $65.85-74.39$ & $66.17-75.20$ & $89.87-97.45$ & $95.37-99.15$ & $104.55-120.48$ & 97.24-107.33 & $34.67-43.32$ & $60.28-72.36$ \\
\hline \multirow{3}{*}{ LB - Kozi Grzbiet } & \begin{tabular}{|l}
$\mathrm{n}$ \\
\end{tabular} & 8 & 9 & 9 & 2 & 9 & \begin{tabular}{|l|}
9 \\
\end{tabular} & 2 & 8 \\
\hline & avr. & 70.16 & 72.54 & 95.31 & 96.22 & 102.79 & 103.01 & 38.95 & 67.70 \\
\hline & min.-max. & $65.20-73.91$ & $66.42-78.26$ & $92.66-98.18$ & $93.46-98.99$ & $97.78-110.84$ & 94.12-108.99 & $37.74-40.16$ & $63.74-74.70$ \\
\hline \multirow{3}{*}{ LB - Kövesvárad } & $n$ & 1 & 1 & 1 & 1 & 1 & 1 & 1 & 1 \\
\hline & avr. & 68.06 & 67.68 & 93.00 & 98.21 & 107.37 & 99.44 & 41.83 & 63.12 \\
\hline & $\min .-\max$. & - & - & - & - & - & - & - & - \\
\hline
\end{tabular}


Table 3. Frequency of selected spelaeoid characters for M1 in \%. HME - metacone height; HPA - paracone height; LMEC - metacone-complex length; LPAC - paracone-complex length; WANT - width of anterior lobe (across Pa); WPOST - width of posterior lobe (across Me).

\begin{tabular}{|l|c|c|c|c|c|c|c|c|c|c|c|c|}
\hline \multicolumn{1}{|c|}{ taxonomical unit } & \multicolumn{4}{|c|}{ HPA/HME } & \multicolumn{3}{c|}{ LPAC/LMEC } & \multicolumn{3}{c|}{ WPOST/WANT } \\
\hline & $\mathrm{n}$ & $>1$ & 1 & $<1$ & $\mathrm{n}$ & $>1$ & 1 & $<1$ & $\mathrm{n}$ & $<1$ & 1 & $>1$ \\
\hline Za Hájovnou - MIS 9 & 5 & $\mathbf{8 0}$ & 0 & 20 & 10 & $\mathbf{1 0 0}$ & 0 & 0 & 9 & $\mathbf{0}$ & 0 & 100 \\
\hline Za Hájovnou - MIS 11 & 10 & $\mathbf{7 0}$ & 0 & 30 & 22 & $\mathbf{9 5}$ & 0 & 5 & 19 & $\mathbf{5}$ & 0 & 95 \\
\hline Za Hájovnou - Chodba naděje & 6 & $\mathbf{6 6}$ & 17 & 17 & 8 & $\mathbf{1 0 0}$ & 0 & 0 & 7 & $\mathbf{1 4}$ & 0 & 86 \\
\hline ET - Mosbach 2 & 17 & $\mathbf{4 1}$ & 24 & 35 & 23 & $\mathbf{8 3}$ & 0 & 17 & 23 & $\mathbf{2 2}$ & 7 & 71 \\
\hline ET - Hundsheim (UniW) & 2 & $\mathbf{0}$ & 0 & 100 & 12 & $\mathbf{8 3}$ & 0 & 17 & 12 & $\mathbf{3 3}$ & 0 & 67 \\
\hline ET - Mauer & 0 & - & - & - & 3 & $\mathbf{1 0 0}$ & 0 & 0 & 3 & $\mathbf{0}$ & 33 & 67 \\
\hline ET - Tarkố & 0 & - & - & - & 2 & $\mathbf{1 0 0}$ & 0 & 0 & 2 & $\mathbf{5 0}$ & 0 & 50 \\
\hline LB - C718 & 5 & $\mathbf{0}$ & 0 & 100 & 18 & $\mathbf{8 9}$ & 5.5 & 5.5 & 17 & $\mathbf{1 8}$ & 6 & 76 \\
\hline LB - Koněprusy Caves & 11 & $\mathbf{0}$ & 0 & 100 & 22 & $\mathbf{1 0 0}$ & 0 & 0 & 23 & $\mathbf{9}$ & 9 & 82 \\
\hline LB - Kozi Grzbiet & 2 & $\mathbf{0}$ & 0 & 100 & 9 & $\mathbf{4 5}$ & 22 & 33 & 9 & $\mathbf{2 2}$ & 0 & 78 \\
\hline LB - Kövesvárad & 1 & $\mathbf{0}$ & 0 & 100 & 1 & $\mathbf{1 0 0}$ & 0 & 0 & 1 & $\mathbf{1 0 0}$ & 0 & 0 \\
\hline
\end{tabular}

Table 4. Metric characteristics and indexes for $\mathrm{M} 2$ from studied and comparative taxonomical units. Measurements in mm, indexes in \%. BLTR - buccal length of trigon; LLTR - lingual length of trigon; LME - metacone length; LMEC - metacone-complex length; LPA paracone length; LPAC - paracone-complex length; MAXL - maximal length; WANT - width of anterior lobe (across Pa); WCON width of constriction; WPOST - width of posterior lobe (across Me) continues on p. 77.

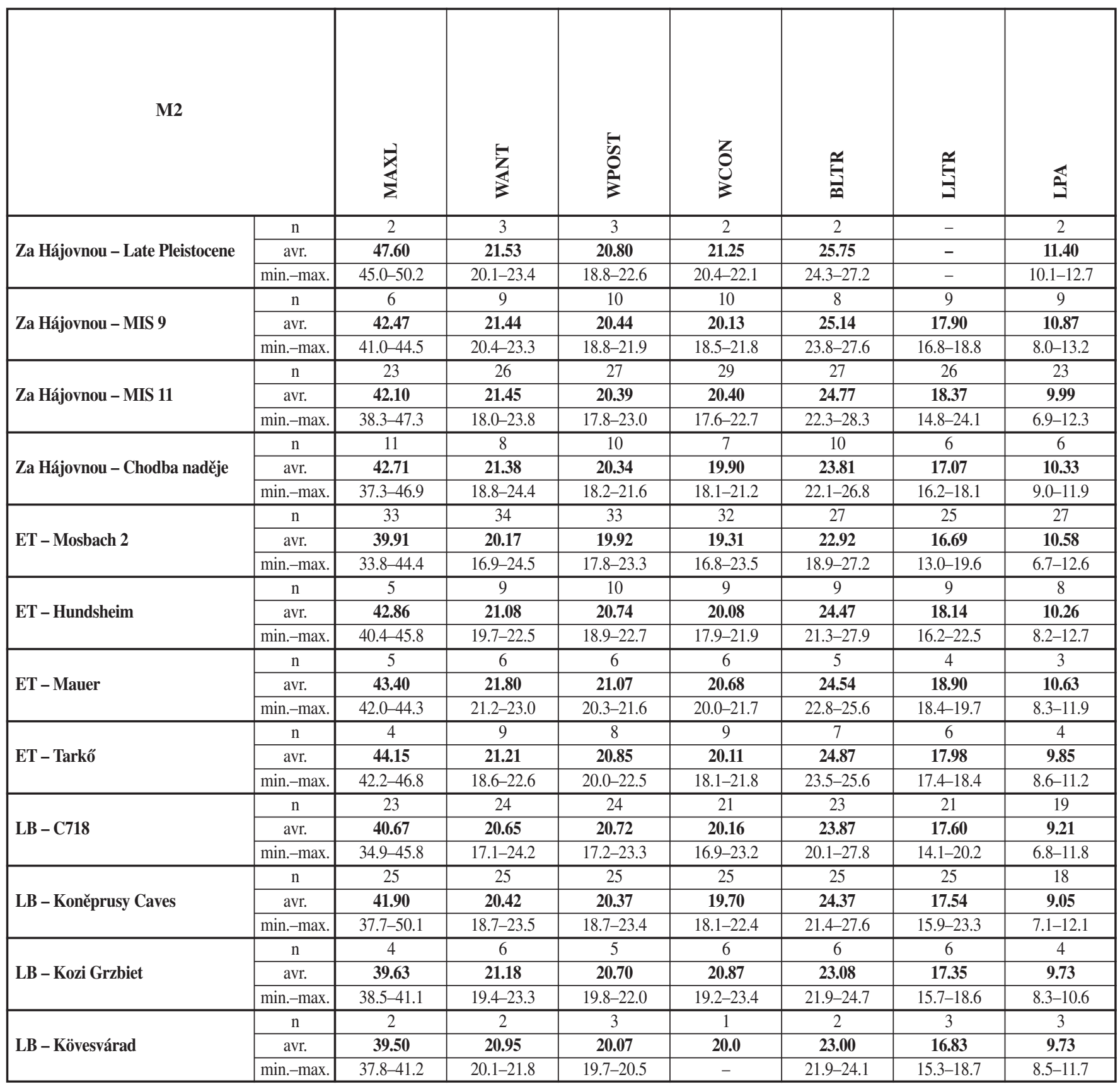


m1 inf. (Tab. 6). The first lower molar is an important tooth with respect to interspecific differentiation in ursines. Unfortunately, the number of $\mathrm{m} 1$ available in most taxonomical units used in present paper is very low and therefore any comparison has only a limited value. Concerning the maximal length, we could see no clinal changes within the units from different stratigraphic levels. Differences seem to be (between Biharian and Toringian samples) in the relative width of the trigonid and talonid, with a tendency towards a wider trigonid and talonid in Toringian populations (incl. Mosbach 2). There is no apparent difference between Early and Middle Toringian units (but this may be caused by the limited number of $\mathrm{m} 1$ ). No trends were detected in the relative width of the constriction in the Middle Pleistocene $U$. deningeri. The significance of the metric characteristic (height and length) of End 1 and End 2 (or their complexes respectively) is debatable. Although there seems to be a trend for an increase in spelaeoid characters (height of End $2 \geq$ height of End 1; length of End 2-c $\geq$ length of End 1-c) from the Biharian to Toringian when we compare the average values, but there is no such apparent trend if we use the median. The lower average values for Biharian units are caused partially by the presence of two specimens (one in C 718 unit and one in Koněprusy Caves unit) without a developed End 2. Also the frequency of specimens with "height of End $2 \geq$ height of End 1" cannot be used for differentiating between units (e.g. 3 from 11 in MIS 11 unit vs. 2 from 12 in Koněprusy Caves unit; 1 in Mosbach 2 and C 718 unit; 0 in MIS 9 unit). But, on the other hand, there are no specimens without End 2 in the Toringian samples. In fact, there is most probably some tendency in (clinal) changes in the End-complex from Biharian to Middle Toringian populations. But these changes are likely to include both metrical and morphological aspects and it is somewhat

Table 4. continuation.

\begin{tabular}{|c|c|c|c|c|c|c|c|c|}
\hline \multicolumn{2}{|l|}{ M2 } & لِ & $\sum^{5}$ & 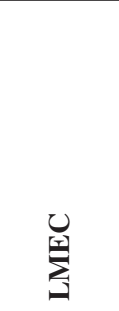 & 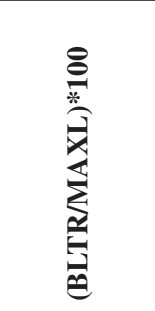 & 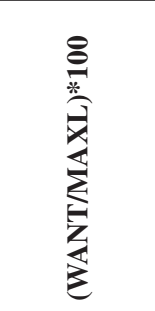 & ${ }_{\substack{0 \\
0}}^{\stackrel{8}{0}}$ & 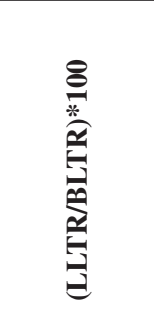 \\
\hline \multirow{3}{*}{ Za Hájovnou - Late Pleistocene } & $\mathrm{n}$ & 3 & 3 & 2 & 2 & 2 & 2 & - \\
\hline & avr. & 13.93 & 7.27 & 11.00 & 54.09 & 46.75 & 45.84 & - \\
\hline & min.-max. & $13.0-14.7$ & $6.9-7.9$ & $9.5-12.5$ & $54.0-54.18$ & $46.61-46.89$ & $45.02-46.67$ & - \\
\hline \multirow{3}{*}{ Za Hájovnou - MIS 9} & $\mathrm{n}$ & 10 & 9 & 8 & 6 & 6 & 6 & 7 \\
\hline & avr. & 13.40 & 7.94 & 11.24 & 58.01 & 50.52 & 47.61 & 71.39 \\
\hline & $\min .-\max$. & $11.7-14.7$ & $5.9-10.9$ & $10.4-13.2$ & $54.34-62.11$ & $49.16-52.36$ & $45.08-50.00$ & $64.49-74.79$ \\
\hline \multirow{3}{*}{ Za Hájovnou - MIS 11} & $\mathrm{n}$ & 24 & 23 & 29 & 23 & 20 & 22 & 26 \\
\hline & avr. & 12.82 & 7.13 & 10.86 & 58.98 & 51.00 & 48.99 & 74.38 \\
\hline & $\min .-\max$ & $10.9-15.4$ & $4.7-.95$ & $9.0-13.1$ & $54.16-64.81$ & $46.39-54.00$ & $45.78-52.20$ & $61.35-104.78$ \\
\hline \multirow{3}{*}{ Za Hájovnou - Chodba naděje } & $\mathrm{n}$ & 10 & 10 & 11 & 10 & 7 & 10 & 5 \\
\hline & avr. & 13.13 & 7.79 & 9.68 & 56.51 & 50.23 & 47.73 & 70.55 \\
\hline & min.-max. & $11.3-15.6$ & $5.8-9.2$ & $8.5-11.0$ & $48.29-62.24$ & $44.87-55.73$ & $45.63-52.28$ & $63.67-73.31$ \\
\hline \multirow{3}{*}{ ET - Mosbach 2} & $\mathrm{n}$ & 27 & 27 & 27 & 26 & 33 & 32 & 25 \\
\hline & \begin{tabular}{|l|} 
avr. \\
\end{tabular} & 12.32 & 8.37 & 9.64 & 57.61 & 50.27 & 49.89 & 72.68 \\
\hline & min.-max. & $10.2-14.7$ & $5.2-12.4$ & $7.3-12.4$ & $52.48-65.38$ & $44.01-57.99$ & $45.75-53.55$ & $59.05-81.12$ \\
\hline \multirow{3}{*}{ ET - Hundsheim } & \begin{tabular}{|c|}
$\mathrm{n}$ \\
\end{tabular} & 6 & 7 & 8 & 5 & 5 & 5 & 8 \\
\hline & avr. & 12.47 & 7.91 & 10.48 & 60.29 & 49.18 & 48.90 & 74.83 \\
\hline & $\min .-\max$. & $11.1-14.3$ & $6.9-9.5$ & $8.4-12.8$ & $54.762-62.59$ & $46.90-52.72$ & $47.82-50.99$ & $66.53-80.65$ \\
\hline \multirow{3}{*}{ ET - Mauer } & $\mathrm{n}$ & 2 & 3 & 5 & 5 & 5 & 5 & 4 \\
\hline & avr. & 12.90 & 7.60 & 10.78 & 56.54 & 50.50 & 48.91 & 76.80 \\
\hline & $\min .-\max$. & $12.8-13.0$ & $7.3-7.9$ & $9.2-12.0$ & $54.29-59.67$ & $47.86-53.61$ & $47.63-50.35$ & $71.88-80.70$ \\
\hline \multirow{3}{*}{ ET - Tarkố } & $\mathrm{n}$ & 3 & 2 & 8 & 4 & 4 & 4 & 6 \\
\hline & avr. & 13.23 & 7.1 & 11.05 & 56.54 & 46.35 & 46.55 & 72.77 \\
\hline & $\min .-\max$ & $12.6-14.4$ & $6.9-7.3$ & $9.0-12.4$ & $51.76-60.19$ & $44.08-48.68$ & $44.71-48.58$ & $68.50-77.87$ \\
\hline \multirow{3}{*}{ LB - C718 } & $\mathrm{n}$ & 22 & 17 & 23 & 3 & 22 & 22 & 20 \\
\hline & avr. & 12.07 & 7.56 & 10.68 & 58.63 & 50.69 & 50.76 & 74.33 \\
\hline & min.-max. & 9.9-14.1 & $6.3-9.8$ & $8.1-13.2$ & $52.59-65.15$ & $47.19-59.45$ & $46.99-63.56$ & $66.16-87.68$ \\
\hline \multirow{3}{*}{ LB - Koněprusy Caves } & $\mathrm{n}$ & 20 & 17 & 25 & 25 & 25 & 25 & 25 \\
\hline & avr. & 12.28 & 7.75 & 11.15 & 58.25 & 48.81 & 48.71 & 72.02 \\
\hline & \begin{tabular}{|l|}
$\min .-\max$ \\
\end{tabular} & $10.9-15.6$ & $6.0-9.7$ & $9.1-14.2$ & $52.94-65.37$ & $45.91-52.72$ & $46.11-53.25$ & $66.01-84.73$ \\
\hline \multirow{3}{*}{ LB - Kozi Grzbiet } & $\mathrm{n}$ & 5 & 7 & 7 & 4 & 4 & 4 & 6 \\
\hline & avr. & 12.22 & 7.39 & 9.84 & 58.44 & 51.55 & 51.43 & 75.27 \\
\hline & $\min .-\max$ & $11.6-12.8$ & $5.8-8.8$ & $8.7-11.6$ & $53.28-64.16$ & $47.20-54.55$ & $50.00-25.99$ & $70.00-84.93$ \\
\hline \multirow{3}{*}{ LB - Kövesvárad } & $\mathrm{n}$ & 3 & 4 & 4 & 2 & 1 & 2 & 2 \\
\hline & avr. & 13.07 & 7.45 & 10.05 & 58.46 & 48.79 & 51.33 & 69.41 \\
\hline & min.-max. & $12.6-13.8$ & $5.4-8.8$ & $8.4-11.7$ & $53.16-63.76$ & - & $49.76-52.91$ & $63.49-75.34$ \\
\hline
\end{tabular}




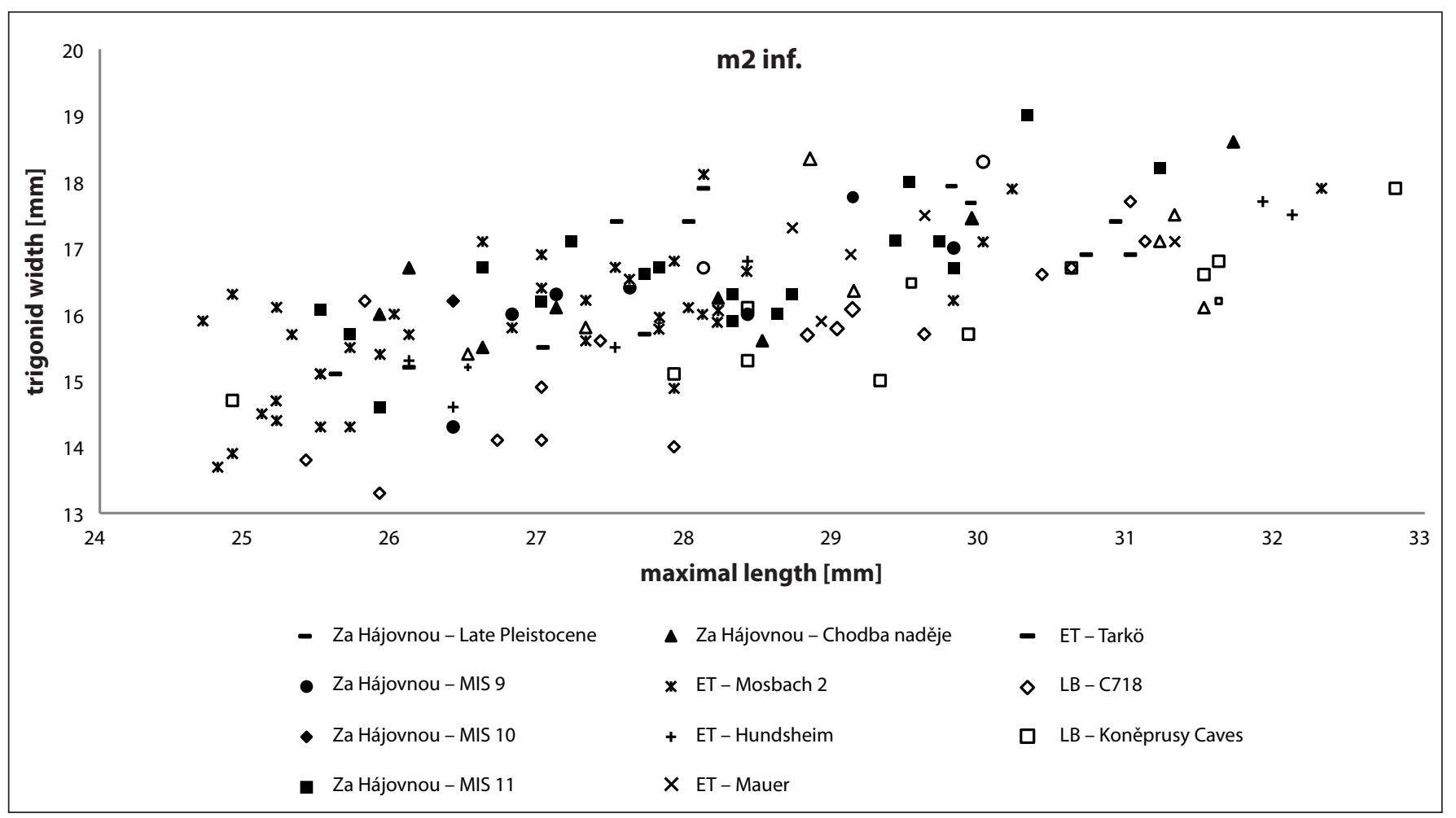

Text-fig. 1. Trigonid width characteristic of $\mathrm{m} 2$ in studied material. The Toringian sample tends to have relatively broader trigonid than the Biharian one.

complicated to express them by simple height/length characteristics, especially based on samples of limited size.

$\mathbf{m} 2$ inf. (Tab. 7). There are no differences in length parameters among the units from different stratigraphic levels. It is interesting that the largest measurements are from Biharian units and, on the other hand, the smallest of these measurements are from Mosbach 2 unit. There are also no trends in "End 2-c length/End 1-c length" index. The surprisingly small value of this index in bears from Tarkő is caused by unusually highly diversified End 1-c in several specimens. Evaluation of the length characteristic of the End-complex is moreover complicated by the frequent presence of a mesostylid which is not included in End 2-c length, but it substitutes End 2-c functionally. There are weak differences between Biharian and Toringian units in trigonid width (Text-fig. 1). The latter units tend to have a relatively wider trigonid (trend within the Toringian is not very clear, although it is not possible to excluded it). Even more apparent differences between these two groups are in the relative distance between Prd and Med (in relation to maximal length). The higher values of this index in Toringian bears probably reflect a more open crown compared to Biharian specimens. This effect is also mirrored in the "distance between Prd-Med/ trigonid width" index. Although the differences in averages are not distinguishable, we can see that samples from Toringian units have higher upper limits. Any differentiation within Toringian units is not apparent. This may have been connected to the limited number of available teeth.

m3 inf. (Tab. 8). The average values do not show any trends in this tooth. There is no apparent tendency towards an increase in the average values of the maximal size or width from Late Biharian to Middle Toringian units. Even the size from LP units falls within the variability of the Early/Middle Toringian samples. But we can see that when considering maximal length, there are higher maxima for Toringian units in comparison to Biharian units. No differences are apparent between Early and Middle Toringian units.

\section{Discussion and conclusions}

\section{Za Hájovnou Cave units}

From only three taxonomical units from Za Hájovnou Cave (MIS 9, MIS 11, and Chodba naděje) are the samples of bear teeth of sufficient size to allow more detailed evaluation and comparison. If we compare them with Late Biharian and Early Toringian samples, all three units from Za Hájovnou Cave clearly correlate with Early Toringian units. But in most of the teeth it is not possible to find any additional pattern within the Toringian units from a metrical viewpoint. The only exception is M1, particularly the metacone to paracone length and height ratios. In this tooth, there is a weak tendency towards a higher percentage of teeth with spelaeoid characters when considering Early to Middle Toringian. On the other hand, it is interesting that all the three units are less spelaeoid in several characters (e.g. anterior/posterior lobe width ratio in M1 or trigonid width/maximal length index in $\mathrm{m} 1$ ) than Ursus gr. deningeri from Bilzingsleben (Musil 1991, 2006; see also comparison in Wagner 2005) for which MIS 11 is usually assumed (e.g. Schreve and Bridgland 2002). I consider that these differences more likely reflect large interpopulation variability within Middle Pleistocene spelaeoid bears. 
Table 5. Metric characteristics and indexes for $\mathbf{p} \mathbf{4}$ from studied and comparative taxonomical units. Measurements in $\mathbf{m m}$, indexes in \%. MAXL - maximal length; MAXW - maximal width.

\begin{tabular}{|c|c|c|c|c|}
\hline p4 & & 齐 & $\frac{\sum}{\sum}$ & 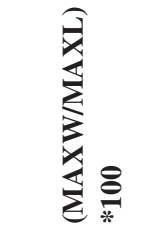 \\
\hline \multirow{3}{*}{$\begin{array}{l}\text { Za Hájovnou - } \\
\text { Late Pleistocene }\end{array}$} & $\mathrm{n}$ & 1 & 1 & 1 \\
\hline & avr. & 16.0 & 9.5 & 59.38 \\
\hline & $\min .-\max$. & - & - & - \\
\hline \multirow{3}{*}{$\begin{array}{l}\text { Za Hájovnou - } \\
\text { MIS } 9\end{array}$} & \begin{tabular}{|c|}
$\mathrm{n}$ \\
\end{tabular} & 3 & 2 & 2 \\
\hline & avr. & 15.87 & 10.65 & 64.19 \\
\hline & $\min .-\max$ & $14.5-17.0$ & 9.4-11.9 & $58.39-70.00$ \\
\hline \multirow{3}{*}{$\begin{array}{l}\text { Za Hájovnou - } \\
\text { MIS } 11\end{array}$} & $\mathrm{n}$ & 8 & 7 & 6 \\
\hline & \begin{tabular}{|c|} 
avr. \\
\end{tabular} & \begin{tabular}{|l|}
14.06 \\
\end{tabular} & 8.89 & 64.50 \\
\hline & $\min .-\max$. & $12.2-15.6$ & 7.9-11.0 & $59.72-70.51$ \\
\hline \multirow{3}{*}{$\begin{array}{l}\text { Za Hájovnou - } \\
\text { Chodba naděje }\end{array}$} & $\begin{array}{l}\mathrm{n} \\
\end{array}$ & 6 & 6 & 6 \\
\hline & \begin{tabular}{|l|} 
avr. \\
\end{tabular} & 12.52 & \begin{tabular}{|l|}
8.30 \\
\end{tabular} & 67.06 \\
\hline & min.-max. & $7.0-15.7$ & 5.2-10.4 & $57.86-74.29$ \\
\hline \multirow{3}{*}{ ET - Mosbach 2} & $\mathrm{n}$ & 13 & 14 & 13 \\
\hline & avr. & 14.70 & 8.91 & 61.05 \\
\hline & min.-max. & $12.9-17.3$ & 7.9-9.8 & $54.34-65.96$ \\
\hline \multirow{3}{*}{ ET - Hundsheim } & $\mathrm{n}$ & 1 & 1 & 1 \\
\hline & avr. & 12.8 & 8.8 & 68.75 \\
\hline & $\min .-\max$ & - & - & - \\
\hline \multirow{3}{*}{ ET - Mauer } & $\mathrm{n}$ & 1 & 1 & 1 \\
\hline & \begin{tabular}{|l|} 
avr. \\
\end{tabular} & 15.0 & 9.3 & 62.00 \\
\hline & $\min .-\max$ & - & - & - \\
\hline \multirow{3}{*}{ ET - Tarkő́ } & $\mathrm{n}$ & 8 & 9 & 8 \\
\hline & avr. & 14.15 & 8.74 & 62.42 \\
\hline & min.-max. & $12.2-16.1$ & \begin{tabular}{|l|}
$7.9-10.6$ \\
\end{tabular} & $55.41-65.84$ \\
\hline \multirow{3}{*}{ LB - C718 } & $\mathrm{n}$ & 7 & 6 & 6 \\
\hline & avr. & 15.46 & 8.67 & 56.51 \\
\hline & min.-max. & $13.8-16.4$ & $7.1-10.2$ & $51.45-62.20$ \\
\hline \multirow{3}{*}{$\begin{array}{l}\text { LB - Koněprusy } \\
\text { Caves }\end{array}$} & $\mathrm{n}$ & 9 & 8 & 8 \\
\hline & \begin{tabular}{|l|} 
avr. \\
\end{tabular} & 14.56 & 8.61 & $\mathbf{5 9 . 3 8}$ \\
\hline & $\min .-\max$. & $13.1-16.0$ & 7.4-9.7 & 56.49-64.18 \\
\hline \multirow{3}{*}{$\begin{array}{l}\text { LB - Kozi } \\
\text { Grzbiet }\end{array}$} & $\mathrm{n}$ & 8 & 9 & 8 \\
\hline & \begin{tabular}{|l|} 
avr. \\
\end{tabular} & \begin{tabular}{|l|}
14.38 \\
\end{tabular} & \begin{tabular}{|l|}
8.99 \\
\end{tabular} & $\begin{array}{r}63.28 \\
\end{array}$ \\
\hline & $\min .-\max$ & $13.1-15.6$ & \begin{tabular}{|l|}
$8.2-9.8$ \\
\end{tabular} & $53.59-70.00$ \\
\hline \multirow{3}{*}{ LB - Kövesvárad } & $\mathrm{n}$ & 4 & 4 & 4 \\
\hline & avr. & 15.70 & 9.33 & 59.56 \\
\hline & min.-max. & $14.6-16.8$ & 8.9-10.1 & $53.614-63.70$ \\
\hline
\end{tabular}

It was not possible to detect any pattern in the differences among MIS 9, MIS 11, and Chodba naděje units. Although it could be assumed that MIS 9 bears would be more spelaeoid than MIS 11 bears, there were no unambiguous metric differences/trends in this direction between these two units. Concerning the Chodba naděje unit, no direct dating for this unit is available. Bears from this unit show more similarity with MIS 9 and MIS 11 units than to other Toringian units, and therefore a post-Elsterian age is probable. But they do not show any special affinity to either MIS 9 or MIS 11 unit. It is therefore not possible to specify their stratigraphic position in more detail on the basis of the studied ursid material only. This comparison is, moreover, complicated by the limited number of specimens in particular samples, especially within MIS 9 unit.

\section{General remarks on dental variability in Middle Pleistocene $U$. gr. deningeri}

Although the comparison was based on only a limited number of localities and specimens, some of the results appear to be of interest and may be more generally valid at least within the Central European area.

(1) If we compare the average values of the studied characters with respect to the main biostratigraphic groups (Late Biharian, Early Toringian, Middle Toringian), differences between the Biharian and Toringian samples can be recognized, but not between the Early and Middle Toringian (except M1). If this is not e.g. an artefact due to the small size of the Middle Toringian samples (cf. more spelaeoid character in the Bilzingsleben material), one explanation could be the more profound impact of MIS 16 glacial compared to MIS 12 glacial on bear populations. Additional studies would be necessary to confirm or reject this possibility.

(2) In several cheekteeth (p4, P4, m3) we found no (or almost no) time-dependent differences/trends. Of course, absence of differentiating metric characters does not mean that there is no morphological differentiation. But it suggests that potential morphological changes/trends did not reach a high enough level to exceed the interpopulation metric differences. It is interesting that this situation is found in teeth which in Late Pleistocene Ursus gr. spelaeus reached an extreme evolutionary level typical for this/these species. Detailed morphological analysis would be the appropriate next step towards a better understanding of changes within Middle Pleistocene spelaeoid bears.

(3) It is necessary to point out that there are large overlaps within all the taxonomical units used and that median values give sometimes a slightly different view than the average. It is almost impossible to determine stratigraphical level on the basis of isolated teeth or small samples.

(4) In several characters, where average values are stratigraphically not diagnostic, the presence of a small number of highly evolved specimens (or contrarily less evolved ones) can characterize different stratigraphic levels. This is in agreement with Rabeder's $(1983,1989)$ results for Late Pleistocene cave bears, where it is often the presence of a rather small percentage of most evolved morphotypes which proved important.

(5) The variability and differences within the taxonomical units from the same stratigraphic level strongly support a concept of mosaic evolution for spelaeoid bears during the Middle Pleistocene. It seems probable that the observed mosaic pattern would increase further if samples from more distant areas are added to the analysis (cf. Grandal d'Anglade and López-González 2004). From this viewpoint, it is inappropriate to approximate one stratigraphical/evolutionary level in evolutionary analysis based on just a single locality. It can also be misleading if the taxonomical unit is formed from a single fossil-rich locality plus one or more other fossil-poor locality(ies). In such a case, the fossil-rich locality character will prevail and the taxonomical unit will not accurately represent the respective stratigraphical/ evolutionary level. 
(6) In this context, the small size of Mosbach 2 specimens is noteworthy (Mosbach 2 is the type locality of $U$. deningeri). In several cheek teeth (the exceptions being $\mathrm{P} 4, \mathrm{p} 4, \mathrm{~m} 3$ and partly $\mathrm{m} 1$ ) the maximal length averages are considerably reduced within Toringian units and are of the same size as in Biharian units (or even smaller). It is complicated to explain this phenomenon at this point (much more material will be necessary for in depth analysis). But some aspects could be connected with the assumed drier environment in Mosbach 2 (Kahlke et al. 2011) or the different taphonomy (Mosbach 2 material originates from fluvial sediments whereas most of the other taxonomical units originates from the cave sediments; but cf. Mauer). It is also interesting that the cheek teeth, in which Mosbach 2 reaches normal size (compared to other Toringian units), are more or less the same as the least diagnostic ones for time-depended changes during Middle Pleistocene.

Table 6. Metric characteristics and indexes for $\mathrm{m} 1$ from studied and comparative taxonomical units. Measurements in $\mathbf{m m}$, indexes in \%. BLTA - buccal length of talonid; BLTR - buccal length of trigonid; HE1 - End 1 height; HE2 - End 2 height; LE1 - End 1-complex length; LE2 - End 2-complex length; LLTA - lingual length of talonid; LLTR - lingual length of trigonid; MAXL - maximal length; RELWCON= $($ WCON/(WTR+WTA $) / 2)) * 100 ;$ WCON - width of constriction; WTA - width of talonid; WTR - width of trigonid, continues on p. 81.

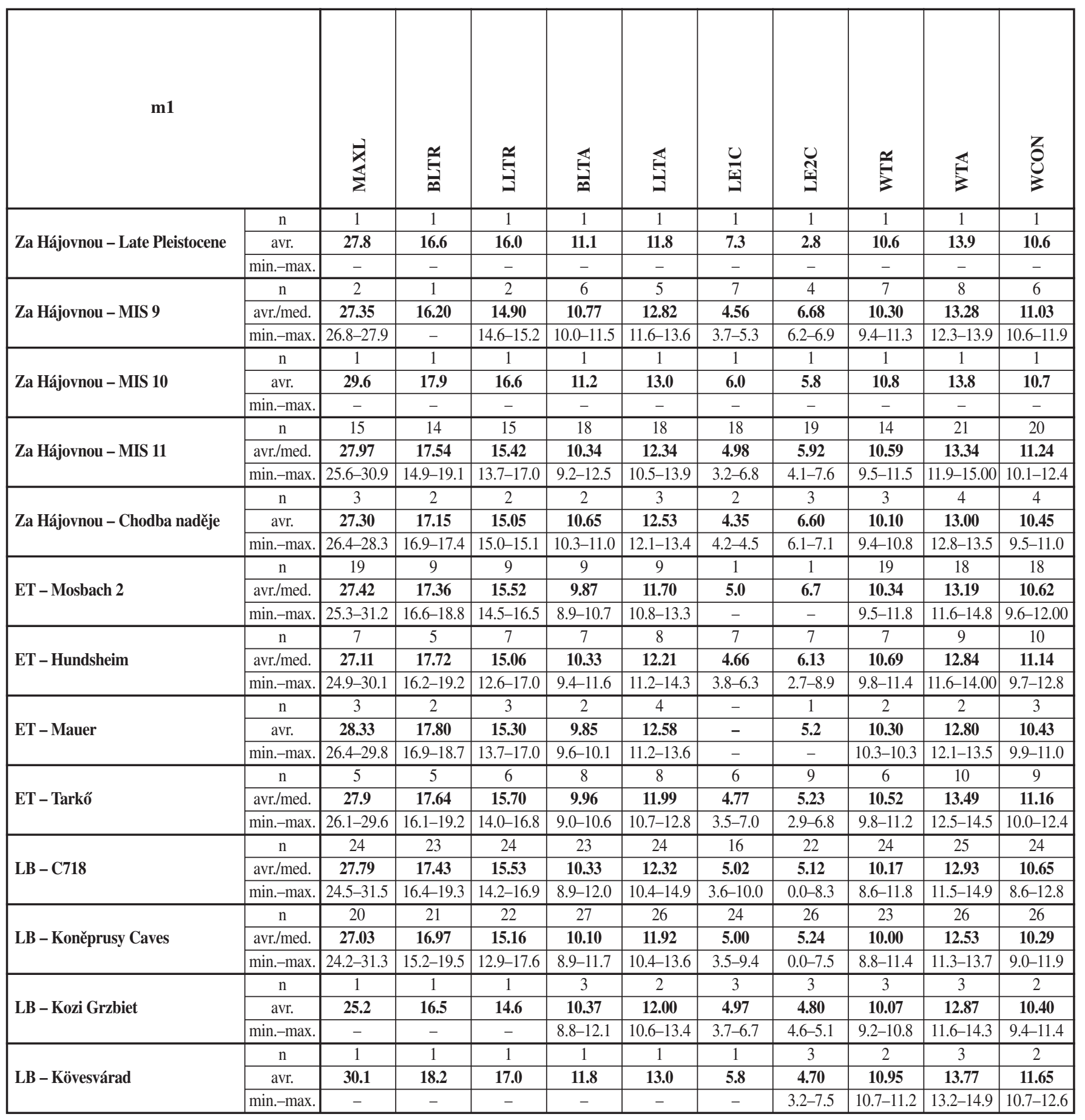




\section{Acknowledgements}

I would like to express my thanks to Rudolf Musil (Masaryk University, Brno) for inviting me to participate in this study of Za Hájovnou Cave ursids. I am also indebted to Martina Roblíčková (Moravian Museum, Brno), who allowed me access to the material from Za Hájovnou Cave under her care, as well as to other colleagues and curators who supported me during my study of Middle Pleistocene ursids.

This work was financially supported by Ministry of Culture of the Czech Republic (DKRVO 2013/04, National Museum, 00023272) and partly by SYNTHESYS Project http://www.synthesys.info/ which is the European Union- funded Integrated Activities grant, an EC-funded project creating an integrated European infrastructure for natural history collections.

\section{References}

Ábelová, M. (2005): Mikroštruktúry zubného cementu medved'ov (Ursidae) [Microstructure of the dental cement of bears (Ursidae)]. - Geologické výzkumy na Moravě a ve Slezsku v roce 2004: 2-4. (in Slovak)

Baryshnikov, G. (1998): Cave bear from the Paleolithic of the Greater Caucasus. - Illinois State Museum Scientific Papers, 27: 69-118.

Table 6. continuation.

\begin{tabular}{|c|c|c|c|c|c|c|c|c|c|c|}
\hline m1 & & 氠 & 空 & 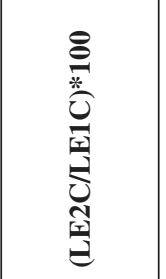 & 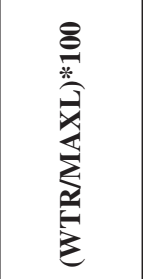 & 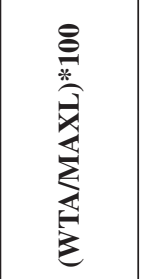 & 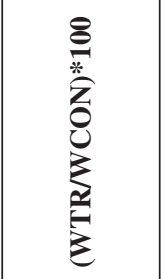 & $\begin{array}{l}z \\
0 \\
0 \\
\text { 空 } \\
\simeq\end{array}$ & 兽 & 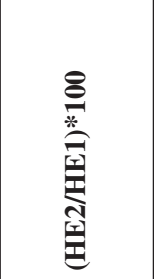 \\
\hline \multirow{3}{*}{ Za Hájovnou - Late Pleistocene } & $\mathrm{n}$ & - & - & 1 & 1 & 1 & 1 & 1 & 1 & - \\
\hline & avr. & - & - & 38.36 & 38.13 & 50.00 & 100.00 & 86.53 & 57.55 & - \\
\hline & min.-max. & - & - & - & - & - & - & - & - & - \\
\hline \multirow{3}{*}{ Za Hájovnou - MIS 9} & $n$ & 4 & 5 & 4 & 2 & 2 & 2 & 2 & 1 & 4 \\
\hline & avr./med. & \begin{tabular}{|l|l|}
8.10 \\
\end{tabular} & 7.46 & $152.45 / 148.86$ & \begin{tabular}{|l|}
37.97 \\
\end{tabular} & \begin{tabular}{|l|}
47.86 \\
\end{tabular} & 91.82 & \begin{tabular}{|l|l|}
94.76 \\
\end{tabular} & 52.33 & 95.28/94.38 \\
\hline & min.-max. & $7.2-8.8$ & $6.4-8.6$ & $\mid 128.30-183.78$ & $35.45-40.50$ & $45.90-49.82$ & $88.68-94.96$ & 94.44-95.07 & - & $93.51-98.85$ \\
\hline \multirow{3}{*}{ Za Hájovnou - MIS 10} & $\mathrm{n}$ & - & - & \begin{tabular}{|l|}
1 \\
\end{tabular} & 1 & \begin{tabular}{|l|}
1 \\
\end{tabular} & 1 & 1 & 1 & - \\
\hline & avr. & - & - & 96.67 & 36.49 & 46.62 & 100.93 & 86.99 & 56.08 & - \\
\hline & min.-max. & - & - & - & - & - & - & - & - & - \\
\hline \multirow{3}{*}{ Za Hájovnou - MIS 11} & $\mathrm{n}$ & 11 & 12 & 18 & 13 & 15 & 13 & 13 & 14 & 11 \\
\hline & avr./med. & 8.02 & 7.30 & $123.48 / 121.53$ & 37.78 & 47.99 & 93.50 & 94.41 & 55.23 & $92.21 / 94.36$ \\
\hline & $\min .-\max$. & $7.0-9.0$ & $6.5-8.8$ & 62.12-184.21 & $34.72-40.94$ & $45.88-50.74$ & $87.72-100.00$ & $88.52-99.59$ & $53.52-58.13$ & $76.14-102.44$ \\
\hline \multirow{3}{*}{ Za Hájovnou - Chodba naděje } & \begin{tabular}{|l|}
$\mathrm{n}$ \\
\end{tabular} & \begin{tabular}{|l|}
1 \\
\end{tabular} & \begin{tabular}{|l|}
1 \\
\end{tabular} & \begin{tabular}{|l|}
2 \\
\end{tabular} & \begin{tabular}{|l|}
3 \\
\end{tabular} & \begin{tabular}{|l|}
3 \\
\end{tabular} & \begin{tabular}{|l|}
3 \\
\end{tabular} & 3 & 2 & \begin{tabular}{|l|}
- \\
\end{tabular} \\
\hline & \begin{tabular}{|l|} 
avr. \\
\end{tabular} & 8.5 & 7.7 & \begin{tabular}{|l|}
151.51 \\
\end{tabular} & \begin{tabular}{|l|}
36.99 \\
\end{tabular} & \begin{tabular}{|l|}
47.88 \\
\end{tabular} & \begin{tabular}{|l|}
98.29 \\
\end{tabular} & 88.95 & 54.26 & - \\
\hline & min.-max. & - & - & 145.24-157.78 & $34.56-38.26$ & $47.06-48.86$ & \begin{tabular}{|l|}
$90.38-106.32$ \\
\end{tabular} & \begin{tabular}{|l|}
$82.61-93.69$ \\
\end{tabular} & $53.00-55.51$ & - \\
\hline \multirow{3}{*}{ ET - Mosbach 2} & $\mathrm{n}$ & 8 & 6 & \begin{tabular}{|l|}
1 \\
\end{tabular} & \begin{tabular}{|l|}
19 \\
\end{tabular} & \begin{tabular}{|l|}
18 \\
\end{tabular} & \begin{tabular}{|l|}
18 \\
\end{tabular} & 18 & 9 & 6 \\
\hline & avr./med. & 8.36 & 7.60 & 134.00 & 37.74 & 47.95 & 97.70 & 90.15 & 56.76 & 91.40 \\
\hline & min.-max. & $7.6-9.3$ & $6.7-8.3$ & - & $34.05-40.47$ & 44.79-54.09 & 90.09-103.13 & $85.22-98.23$ & $53.70-59.14$ & $83.75-100.00$ \\
\hline \multirow{3}{*}{ ET - Hundsheim } & $n$ & 1 & 2 & 7 & 6 & \begin{tabular}{|l|}
7 \\
\end{tabular} & \begin{tabular}{|l|}
7 \\
\end{tabular} & 6 & 7 & 1 \\
\hline & avr./med. & 7.8 & 7.65 & 138.49/137.21 & \begin{tabular}{|l|}
38.78 \\
\end{tabular} & 46.83 & 97.37 & 92.50 & 55.51 & 91.03 \\
\hline & min.-max. & - & $7.1-8.2$ & 42.86.202.63 & 37.21-41.37 & 44.62-49.47 & 93.33-101.03 & 90.65-95.24 & $50.60-60.07$ & - \\
\hline \multirow{3}{*}{ ET - Mauer } & $\mathrm{n}$ & - & - & \begin{tabular}{|l|}
- \\
\end{tabular} & \begin{tabular}{|l|}
2 \\
\end{tabular} & \begin{tabular}{|l|}
1 \\
\end{tabular} & \begin{tabular}{|l|}
2 \\
\end{tabular} & 1 & 3 & - \\
\hline & avr. & - & - & - & 37.39 & 51.14 & 96.34 & 92.44 & 53.91 & - \\
\hline & $\min .-\max$. & - & - & - & $35.76-39.02$ & - & $93.64-99.04$ & - & $51.89-57.05$ & - \\
\hline \multirow{3}{*}{ ET - Tarkố } & $\mathrm{n}$ & - & - & 6 & 5 & 5 & 6 & 6 & 5 & - \\
\hline & avr./med. & - & - & 114.81/118.13 & \begin{tabular}{|l|}
37.69 \\
\end{tabular} & 48.12 & 94.04 & 93.54 & 56.62 & - \\
\hline & min.-max. & - & - & \begin{tabular}{|l|}
$41.43-151.43$ \\
\end{tabular} & $37.19-38.31$ & $46.32-49.81$ & 91.80-100.00 & $86.96-96.06$ & $53.23-58.62$ & - \\
\hline \multirow{3}{*}{ LB - C718 } & $\mathrm{n}$ & 8 & 8 & \begin{tabular}{|l|}
16 \\
\end{tabular} & 24 & 24 & \begin{tabular}{|l|}
23 \\
\end{tabular} & 23 & 23 & 8 \\
\hline & avr./med. & 8.275 & 6.58 & 104.16/105.27 & 36.60 & 4 46.64 & 94.95 & 92.69 & 55.64 & 79.41/89.57 \\
\hline & min.-max. & $7.6-9.0$ & $0.0-8.1$ & \begin{tabular}{|l|}
$0.00-152.08$ \\
\end{tabular} & $33.80-43.38$ & 44.36-52.21 & 88.79-101.06 & $85.57-100.00$ & $51.80-61.76$ & \begin{tabular}{|l|}
$0.00-100.00$ \\
\end{tabular} \\
\hline \multirow{3}{*}{ LB - Koněprusy Caves } & \begin{tabular}{|l|}
$\mathrm{n}$ \\
\end{tabular} & 12 & \begin{tabular}{|l|}
12 \\
\end{tabular} & \begin{tabular}{|l|}
23 \\
\end{tabular} & \begin{tabular}{|l|}
20 \\
\end{tabular} & \begin{tabular}{|l|}
19 \\
\end{tabular} & \begin{tabular}{|l|}
20 \\
\end{tabular} & 20 & 20 & 12 \\
\hline & avr./med. & 8.35 & 7.17 & \begin{tabular}{|l|}
$114.12 / 127.66$ \\
\end{tabular} & \begin{tabular}{|l|}
36.89 \\
\end{tabular} & \begin{tabular}{|l|}
46.42 \\
\end{tabular} & 97.44 & 90.97 & 55.94 & $86.24 / 93.25$ \\
\hline & $\min .-\max$. & $7.6-9.4$ & $0.0-8.6$ & |0.00-170.24 & $33.33-40.08$ & $42.71-49.45$ & 92.44-103.33 & 86.09-96.36 & $51.08-60.61$ & $0.00-101.28$ \\
\hline \multirow{3}{*}{ LB - Kozi Grzbiet } & $\mathrm{n}$ & 1 & 2 & \begin{tabular}{|l|}
3 \\
\end{tabular} & 1 & \begin{tabular}{|l|}
1 \\
\end{tabular} & \begin{tabular}{|l|}
2 \\
\end{tabular} & 2 & 1 & 1 \\
\hline & \begin{tabular}{|l|} 
avr. \\
\end{tabular} & 9.2 & 7.75 & 103.65/104.44 & 36.51 & 46.03 & 96.30 & \begin{tabular}{|l|}
90.61 \\
\end{tabular} & 57.94 & 92.39 \\
\hline & min.-max. & - & $7.0-8.5$ & 68.66-137.84 & - & - & $94.74-97.87$ & $90.38-90.84$ & - & - \\
\hline \multirow{3}{*}{ LB - Kövesvárad } & $\mathrm{n}$ & - & - & \begin{tabular}{|l|}
1 \\
\end{tabular} & 1 & 1 & 2 & 2 & 1 & - \\
\hline & avr. & - & - & 129.31 & 37.21 & 49.50 & 94.44 & 93.05 & 56.48 & - \\
\hline & min.-max. & - & - & - & - & - & 88.89-100.00 & $89.54-96.55$ & - & - \\
\hline
\end{tabular}


Baryshnikov, G. F. (2007): Fauna of Russia and neighbouring countries. Mammals. Ursidae. - Nauka, Saint Petersburg, 541 pp. (in Russian)

Doláková, N. (2007): Palynological studies in the Cave sediments from the Moravian, Javoříčko and Hranice Karsts - Czech Republic. - Scripta Facultatis Scientiarum Naturalium Universitatis Masarykianae Brunensis, 35: 47-52.

Doláková, N. (2014): Palynological analysis of sediments from the Za Hájovnou Cave. - Acta Musei Nationalis Pragae, Ser. B, Historia Naturalis, 70(1-2): 35-42.

Fejfar, O., Heinrich, W.-D. (1983): Arvicoliden-Sukzession und Biostratigraphie des Oberpliozäns und Quartärs in Europa. - Schriftenreihe für Geologische Wissenschaften, 19/20: 61-109.

Fejfar, O., Heinrich, W.-D. (1990): Proposed biochronical division of the European continental Neogene and Quaternary based on Muroid rodents (Rodentia, Mammalia).

Table 7. Metric characteristics and indexes for $\mathbf{m} 2$ from studied and comparative taxonomical units. Measurements in $\mathbf{m m}$, indexes in $\%$. BLTA - buccal length of talonid); BLTR - buccal length of trigonid; DPR-ME - distance between apexes of Prd and Med; HE1 - End 1 height; HE2 - End 2 height; LE1 - End 1-complex length; LE2 - End 2-complex length; LLTA - lingual length of talonid; LLTR - lingual length of trigonid; MAXL - maximal length; RELWCON = $($ WCON $/((W T R+W T A) / 2)) * 100$; WCON - width of constriction; WTA width of talonid; WTR - width of trigonid, continues on p. 83.

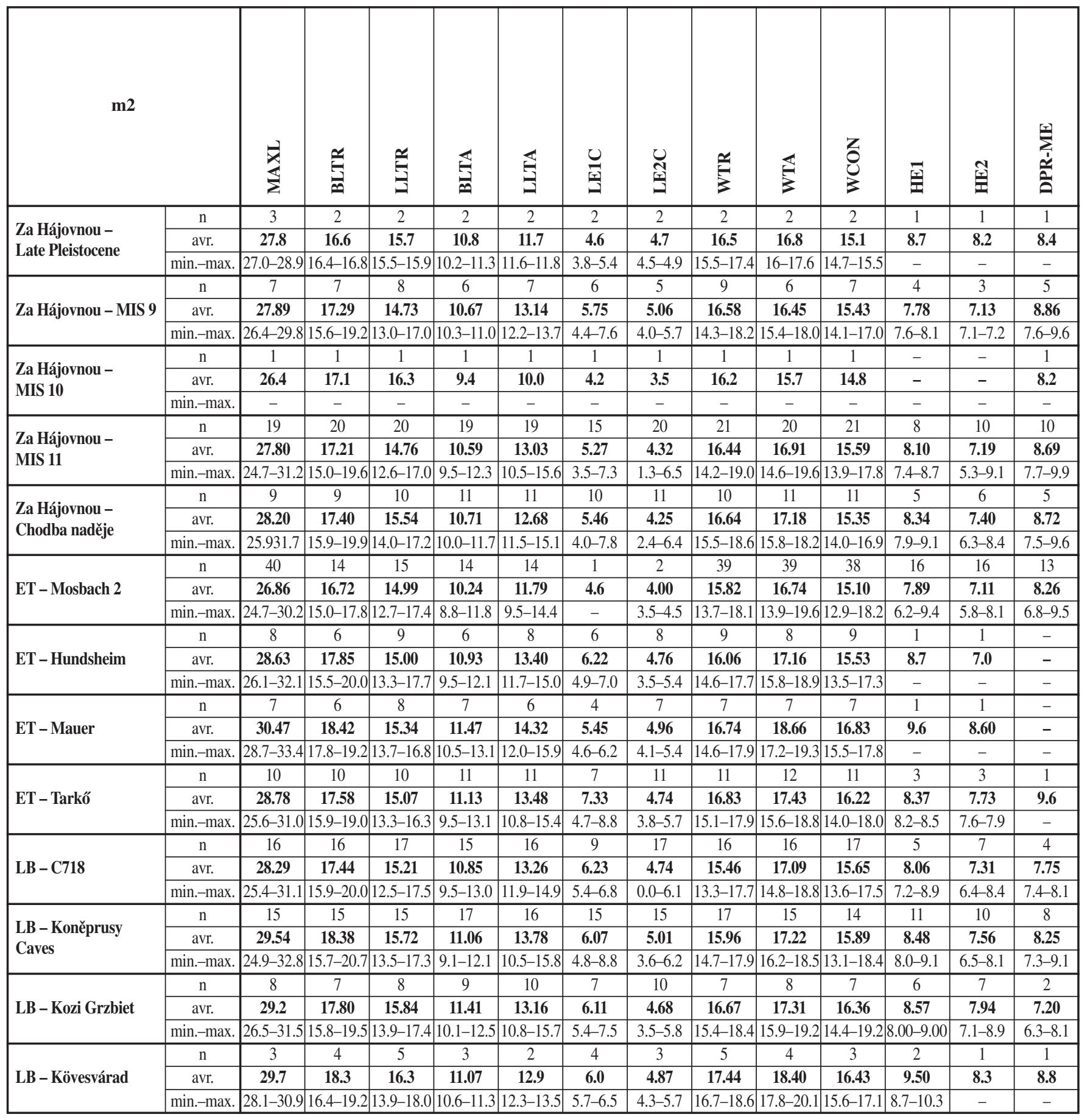


- In: Fejfar, O., Heinrich, W.-D. (eds), International Symposium Evolution, Phylogeny and Biostratigraphy of Arvicolidae (Rodentia, Mammalia), Geological Survey, Prague, pp. 115-124.

Fejfar, O., Heinrich, W.-D., Lindsay, E. H. (1998): Updating the Neogene rodent biochronology in Europe. Mededelingen Nederlands Instituut voor Toegepaste Geowetenschappen TNO, 60: 533-554.

Gibbard, P., Cohen, K. M. (2008): Global chronostratigraphical correlation table for the last 2.7 million years.

- Episode, 31: 243-247.

Gibbard, P., Head, M. J. (2009a): The Definition of the
Quaternary System/Period and the Pleistocene Series/ Epoch. - Quaternaire, 20: 125-133.

http://dx.doi.org/10.4000/quaternaire.5086

Gibbard, P., Head, M. J. (2009b): IUGS ratification of the Quaternary System/Period and the Pleistocene Series/ Epoch with a base at 2.58 MA. - Quaternaire, 20: 411-412. http://dx.doi.org/10.4000/quaternaire.5289

Grandal d'Anglade, A., López-González, F. (2004): A study of the evolution of the Pleistocene cave bear by a morphometric analysis of the lower carnassial. - Oryctos, 5: 83-94. Ivanov, M. (2007): Fossil vertebrates from karstic areas in Moravia with respect to the Moravian Karst, Czech

Table 7. continuation.

\begin{tabular}{|c|c|c|c|c|c|c|c|c|c|c|}
\hline $\mathbf{m} 2$ & & 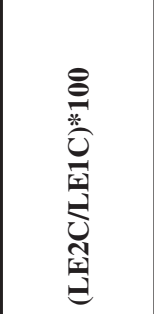 & 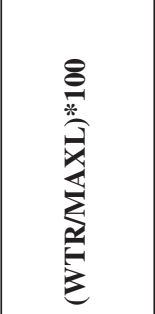 & 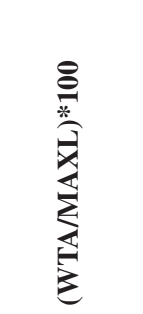 & $\begin{array}{l}z \\
0 \\
0 \\
0 \\
\text { 空 }\end{array}$ & 章 & 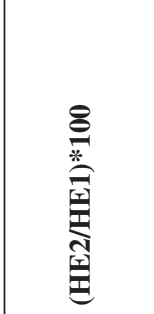 & 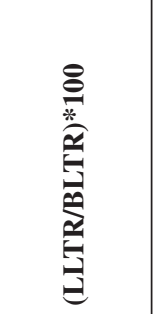 & 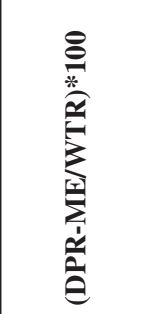 & 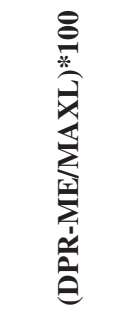 \\
\hline \multirow{3}{*}{$\begin{array}{l}\text { Za Hájovnou - } \\
\text { Late Pleistocene }\end{array}$} & $\mathrm{n}$ & 2 & 2 & 2 & 2 & 2 & 1 & 2 & 1 & 1 \\
\hline & avr. & 106.14 & 60.34 & 61.63 & 90.95 & 57.61 & 94.25 & 94.61 & 48.28 & 30.22 \\
\hline & min.-max. & $83.33-128.95$ & 57.41-63.27 & $59.26-64.00$ & $88.57-93.33$ & $57.41-57.82$ & - & $92.26-96.95$ & - & - \\
\hline \multirow{3}{*}{ Za Hájovnou - MIS 9} & $\mathrm{n}$ & 4 & \begin{tabular}{l|}
7 \\
\end{tabular} & 5 & 5 & 7 & 3 & 7 & 5 & 3 \\
\hline & avr. & 93.72 & 58.28 & 58.76 & 94.24 & 52.28 & 91.11 & 84.45 & 53.62 & 30.84 \\
\hline & min.-max. & $52.63-118.18$ & $54.167-61.17$ & $55.03-61.86$ & $89.82-96.66$ & 47.46-58.05 & 88.89-93.42 & $74.01-91.35$ & $50.00-55.81$ & $28.79-33.21$ \\
\hline \multirow{3}{*}{$\begin{array}{l}\text { Za Hájovnou - } \\
\text { MIS } 10\end{array}$} & $\mathrm{n}$ & 1 & 1 & 1 & 1 & 1 & - & 1 & 1 & 1 \\
\hline & avr. & 83.33 & 61.36 & 59.47 & 92.79 & 61.74 & - & 95.32 & 50.62 & 31.06 \\
\hline & $\min .-\max$. & - & - & - & - & - & - & - & - & - \\
\hline \multirow{3}{*}{$\begin{array}{l}\text { Za Hájovnou - } \\
\text { MIS } 11\end{array}$} & $\mathrm{n}$ & 15 & 18 & 18 & 20 & 19 & 8 & 20 & 10 & 10 \\
\hline & \begin{tabular}{|l|} 
avr. \\
\end{tabular} & \begin{tabular}{|l|}
78.09 \\
\end{tabular} & \begin{tabular}{|l|}
59.28 \\
\end{tabular} & 60.89 & 93.00 & \begin{tabular}{|l|}
53.10 \\
\end{tabular} & \begin{tabular}{|l|}
86.54 \\
\end{tabular} & 85.84 & 52.95 & 30.94 \\
\hline & min.-max. & 28.89-127.27 & 53.18-62.87 & $54.68-67.65$ & $89.22-96.84$ & $48.51-60.15$ & $69.05-98.65$ & $75.38-94.12$ & $46.71-63.38$ & $28.06-33.71$ \\
\hline \multirow{3}{*}{$\begin{array}{l}\text { Za Hájovnou - } \\
\text { Chodba naděje }\end{array}$} & $\mathrm{n}$ & 10 & 8 & 9 & 8 & 9 & 5 & 9 & 5 & 4 \\
\hline & avr. & 80.63 & 59.10 & 61.03 & 91.33 & 55.06 & 89.01 & 89.27 & 52.32 & 31.00 \\
\hline & min.-max. & 42.86-133.33 & \begin{tabular}{|l|}
$54.74-63.98$ \\
\end{tabular} & 57.41-68.97 & 86.69-95.15 & $51.42-57.53$ & $79.75-97.62$ & $83.42-92.97$ & 44.91-59.26 & 27.76-34.04 \\
\hline \multirow{3}{*}{ ET - Mosbach 2} & $\mathrm{n}$ & $\begin{array}{l}1 \\
\end{array}$ & 38 & 38 & 38 & 14 & 16 & 14 & 13 & 13 \\
\hline & avr. & 97.83 & 59.15 & 62.37 & 92.79 & 56.59 & 90.23 & 90.55 & 52.53 & 30.94 \\
\hline & min.-max. & - & 53.41-65.46 & 54.09-69.75 & $81.76-98.31$ & 50.57-63.04 & $81.08-100.00$ & 83.02-99.43 & $46.71-59.01$ & $27.42-34.90$ \\
\hline \multirow{3}{*}{ ET - Hundsheim } & $\mathrm{n}$ & 5 & 7 & 7 & 7 & 8 & 1 & 6 & - & - \\
\hline & \begin{tabular}{|l|} 
avr. \\
\end{tabular} & \begin{tabular}{|l|}
75.85 \\
\end{tabular} & \begin{tabular}{|l|}
56.69 \\
\end{tabular} & 60.96 & 92.83 & \begin{tabular}{|l|}
53.15 \\
\end{tabular} & 80.46 & 86.95 & - & - \\
\hline & min.-max. & 51.47-102.04 & \begin{tabular}{|l|}
$54.52-59.15$ \\
\end{tabular} & $57.45-64.37$ & $88.24-95.33$ & $50.76-55.85$ & - & $82.66-93.55$ & - & - \\
\hline \multirow{3}{*}{ ET - Mauer } & $\mathrm{n}$ & \begin{tabular}{|l|}
4 \\
\end{tabular} & 6 & 6 & 6 & 6 & 1 & 6 & - & - \\
\hline & avr. & 90.12 & 57.09 & 62.43 & 94.03 & 52.34 & 89.58 & 85.10 & - & - \\
\hline & min.-max. & 82.26-94.64 & $54.63-60.28$ & $59.44-66.90$ & $88.57-96.07$ & 48.31-58.54 & - & 79.89-94.38 & - & - \\
\hline \multirow{3}{*}{ ET - Tarkő } & $\mathrm{n}$ & \begin{tabular}{|l|}
7 \\
\end{tabular} & 10 & 10 & 11 & 10 & 3 & 10 & 1 & 1 \\
\hline & avr. & 66.95 & 58.49 & 61.22 & 94.22 & 52.41 & 92.47 & 85.79 & $\begin{array}{l}55.17 \\
\end{array}$ & 31.07 \\
\hline & min.-max. & 50.00-106.38 & $54.52-63.70$ & $57.74-66.90$ & $89.20-100.28$ & $48.32-57.04$ & $89.41-96.34$ & $77.42-92.40$ & - & - \\
\hline \multirow{3}{*}{ LB - C718 } & $\mathrm{n}$ & \begin{tabular}{|l|}
9 \\
\end{tabular} & 16 & 15 & 15 & 16 & 5 & 16 & 4 & 4 \\
\hline & avr. & 77.53 & 54.65 & 60.13 & 96.55 & \begin{tabular}{|l|}
53.41 \\
\end{tabular} & 92.08 & 87.18 & 52.12 & 27.59 \\
\hline & min.-max. & 54.39-103.70 & $50.18-62.79$ & $57.14-67.44$ & 93.15-100.67 & 48.26-58.52 & $82.02-100.00$ & $77.16-98.25$ & $48.50-55.71$ & $26.47-28.52$ \\
\hline \multirow{3}{*}{$\begin{array}{l}\text { LB - Koněprusy } \\
\text { Caves }\end{array}$} & $\mathrm{n}$ & 15 & 15 & 13 & 14 & 15 & 10 & 15 & 8 & 8 \\
\hline & \begin{tabular}{|l|} 
avr. \\
\end{tabular} & \begin{tabular}{|l|}
84.79 \\
\end{tabular} & 54.56 & 58.60 & 95.34 & 53.30 & 89.40 & 85.68 & 51.20 & 27.60 \\
\hline & min.-max. & 56.82-106.25 & 51.19-59.04 & $55.56-62.71$ & $82.65-103.95$ & $48.39-57.43$ & $80.25-95.06$ & 76.70-92.74 & $48.19-53.85$ & $24.91-30.54$ \\
\hline \multirow{3}{*}{ LB - Kozi Grzbiet } & $\mathrm{n}$ & \begin{tabular}{|l|}
7 \\
\end{tabular} & 7 & 8 & 7 & 8 & 6 & 7 & 1 & 1 \\
\hline & avr. & 72.44 & 56.87 & 59.27 & 95.55 & 54.23 & 90.84 & 90.78 & 47.37 & 25.96 \\
\hline & min.-max. & 60.00-87.88 & 51.11-63.89 & $54.92-66.67$ & $91.53-101.86$ & $50.16-58.11$ & $84.27-98.82$ & $83.60-97.47$ & - & - \\
\hline \multirow{3}{*}{ LB - Kövesvárad } & \begin{tabular}{|l|}
$\mathrm{n}$ \\
\end{tabular} & \begin{tabular}{|c|}
3 \\
\end{tabular} & 2 & 2 & 3 & 2 & 1 & 3 & 1 & - \\
\hline & avr. & 83.19 & 60.22 & 61.34 & 93.52 & 56.63 & 95.40 & 89.66 & $\mathbf{5 2 . 0 7}$ & - \\
\hline & min.-max. & 75.44-93.44 & $59.43-61.00$ & $59.33-63.35$ & $90.43-95.40$ & $55.00-58.25$ & - & $85.94-95.74$ & - & - \\
\hline
\end{tabular}


Table 8. Metric characteristics and indexes for $\mathrm{m} 3$ from studied and comparative taxonomical units. Measurements in mm, indexes in \% . BLTR - buccal length of trigonid; MAXL - maximal length; MAXW - maximal width; WTR - width of trigonid.

\begin{tabular}{|c|c|c|c|c|c|c|}
\hline m3 & & $\stackrel{\vec{x}}{\sum}$ & 焗 & $\sum_{i}^{3}$ & $\stackrel{ }{3}$ & $\sum_{*}^{3}$ \\
\hline \multirow{3}{*}{ Za Hájovnou - Late Pleistocene } & $\mathrm{n}$ & 1 & 1 & 1 & 1 & 1 \\
\hline & avr. & 28.4 & 19.8 & 19.6 & 18.5 & 65.14 \\
\hline & $\min .-\max$. & - & - & - & - & - \\
\hline \multirow{3}{*}{ Za Hájovnou - MIS 9} & $\mathrm{n}$ & 4 & 6 & 4 & 6 & 4 \\
\hline & avr. & 24.25 & 15.42 & 17.55 & 18.07 & 72.07 \\
\hline & $\min .-\max$. & $23.2-25.2$ & $13.1-17.4$ & $16.9-18.2$ & $16.7-19.5$ & $70.17-73.71$ \\
\hline \multirow{3}{*}{ Za Hájovnou - MIS 11} & $\mathrm{n}$ & 16 & 15 & 17 & 17 & 15 \\
\hline & avr. & 25.12 & 14.93 & 18.52 & 18.25 & 72.70 \\
\hline & $\min .-\max$. & $22.8-29.4$ & $12.4-18.7$ & $17.0-20.5$ & $16.6-19.8$ & $61.56-88.33$ \\
\hline \multirow{3}{*}{ Za Hájovnou - Chodba naděje } & $\mathrm{n}$ & 8 & 6 & 6 & 7 & 7 \\
\hline & avr. & 23.75 & 14.00 & 18.60 & 18.14 & $\mathbf{7 7 . 2 0}$ \\
\hline & $\min .-\max$. & $20.6-28.6$ & $12.4-15.7$ & $17.0-22.7$ & $16.7-20.2$ & $66.43-86.10$ \\
\hline \multirow{3}{*}{ ET - Mosbach 2} & $\mathrm{n}$ & 6 & 6 & 6 & 6 & 6 \\
\hline & avr. & 23.82 & 14.28 & 17.52 & 17.25 & 73.20 \\
\hline & $\min .-\max$. & $19.8-29.6$ & $11.8-16.4$ & $15.1-20.4$ & $14.9-20.3$ & $62.61-83.92$ \\
\hline \multirow{3}{*}{ ET - Hundsheim } & $\mathrm{n}$ & 8 & 7 & 6 & 7 & 7 \\
\hline & avr. & 24.60 & 15.19 & 18.15 & 18.03 & 73.59 \\
\hline & $\min .-\max$. & $23.8-25.7$ & $13.2-16.9$ & $16.6-19.9$ & $16.5-19.9$ & $67.90-83.61$ \\
\hline \multirow{3}{*}{ ET - Mauer } & $\mathrm{n}$ & 4 & 3 & 3 & 3 & 3 \\
\hline & avr. & 27.60 & 15.40 & 18.70 & 18.23 & 71.48 \\
\hline & $\min .-\max$. & $24.7-33.7$ & $14.8-15.7$ & $18.3-19.3$ & $17.7-18.8$ & $66.67-76.11$ \\
\hline \multirow{3}{*}{ ET - Tarkó } & $\mathrm{n}$ & 6 & 8 & 6 & 9 & 6 \\
\hline & avr. & 25.65 & 15.18 & 18.05 & $\mathbf{1 7 . 5 2}$ & 68.68 \\
\hline & $\min .-\max$. & $23.8-27.3$ & $12.1-17.3$ & $15.8-19.5$ & $15.4-19.2$ & $65.47-70.33$ \\
\hline \multirow{3}{*}{ LB - C718 } & $\mathrm{n}$ & 14 & 13 & 14 & 14 & 13 \\
\hline & avr. & 24.18 & 14.62 & 18.81 & 17.81 & 74.12 \\
\hline & $\min .-\max$. & $20.3-26.3$ & $12.9-17.3$ & $15.9-21.4$ & $15.9-20.3$ & $65.89-81.22$ \\
\hline \multirow{3}{*}{ LB - Koněprusy Caves } & $\mathrm{n}$ & 20 & 20 & 21 & 21 & 20 \\
\hline & avr. & 25.04 & 15.47 & 18.05 & 17.82 & 71.17 \\
\hline & $\min .-\max$. & $22.5-28.00$ & $13.5-18.4$ & $16.2-21.7$ & $16.1-21.4$ & $63.77-79.85$ \\
\hline \multirow{3}{*}{ LB - Kozi Grzbiet } & $\mathrm{n}$ & 7 & 8 & 4 & 7 & 6 \\
\hline & avr. & 24.30 & 15.43 & 18.20 & 17.87 & 74.49 \\
\hline & $\min .-\max$. & $20.0-26.4$ & $13.3-16.3$ & $16.9-20.0$ & $16.9-19.7$ & $68.73-85.00$ \\
\hline \multirow{3}{*}{ LB - Kövesvárad } & $\mathrm{n}$ & 5 & 5 & 5 & 4 & 4 \\
\hline & avr. & 23.46 & 14.66 & 17.88 & 17.13 & 73.45 \\
\hline & $\min .-\max$. & $21.4-28.5$ & $11.8-16.8$ & $17.0-19.5$ & $16.8-19.4$ & $61.05-84.72$ \\
\hline
\end{tabular}

Republic. - Scripta Facultatis Scientiarum Naturalium Universitatis Masarykianae Brunensis, 35: 53-64.

Jánossy D. (1976): Die Felsnische Tarkő und die Vertebratenfauna ihrer Ausfüllung. - Karszt- és Barlangkutatás, 8: 3-106.

Kahlke, R.-D., García, N., Kostopoulos D. S., Lacombat, F., Lister, A. M., Mazza, P. P. A., Spassov, N., Titov, V. V. (2011): Western Palaearctic palaeoenvironmental conditions during the Early and early Middle Pleistocene inferred from large mammal communities, and implications for hominid dispersal in Europe. Quaternary Science Reviews, 30: 1368-1395.

http://dx.doi.org/10.1016/j.quascirev.2010.07.020

Koenigswald, W. von, Heinrich, W.-D. (1999): Mittelpleistozäne Säugetierfaunen aus Mitteleuropa - der Versuch einer biostratigraphischen Zuordnung. - Kaupia, Darmstädter Beiträge zur Naturgeschichte, 9: 53-112.
Kurtén, B. (1955): Contribution to the history of a mutation during 1,000,000 years. - Evolution, 9: 107-118. http://dx.doi.org/10.2307/2405583

Kurtén, B. (1959): On the Bears of the Holsteinian Interglacial. - Stockholm Contributions in Geology, 2: 73-102.

Lundberg, J., Musil, R., Martin S. (2014): Sedimentary history of Za Hájovnou Cave (Moravia, Czech Republic): A unique Middle Pleistocene palaeontological site. - Quaternary International, 339-340: $11-24$.

http://dx.doi.org/10.1016/j.quaint.2013.04.006

Maul, L. Ch., Heinrich, W.-D. (2007): Neue Daten zur Kleinsäugerbiostratigraphie und Altersabfolge deutscher Quartärfundstellen. - Beiträge zur Ur- und Frühgeschichte Mitteleuropas, 48: 96-110.

Maul, L. Ch., Rekovets, L., Heinrich, W.-D., Keller, T., Storch, G. (2000): Arvicola mosbachensis (SCHMIDTGEN 
1911) of Mosbach 2: a basic sample for the early evolution of the genus and references for further biostratigraphical studies. - Senckenbergiana lethaea, 80: 129-147.

Musil, R. (1991): Die Bären von Bilzingsleben. - In: Fischer, K., Guenther, E. W., Heinrich, W.-D., Mania, D., Musil, R., Nötzold, T. (eds), Bilzingsleben IV. Homo erectus seine Kultur und seine Umwelt. Veröffentlichungen des Landesmuseums für Vorgeschichte in Halle, 44: 81-102.

Musil, R. (2005a): Jeskyně „Za Hájovnou“, výjimečná lokalita Javorríčského krasu [Za Hájovnou Cave, exceptional locality of Javoříčko Karst, Moravia]. Př́rodovědné studie Muzea Prostějovska, 8: 9-41. (in Czech)

Musil, R. (2005b): Metapodia a prstní články medvědů z jeskyně „Za Hájovnou“, Javoříčský kras [Metapodia and phalanges of bears from "Za Hájovnou" Cave, Javoříčko Cave System, Moravia.]. - Př́rodovědné studie Muzea Prostějovska, 8: 143-151. (in Czech)

Musil, R. (2006): Die Bärenpopulation von Bilzingsleben eine neue mittelpleistozäne Art. - MUNIBE (AntropologiaArkeologia), 57: 67-101.

Nývltová-Fišáková, M. (2005): Paleopatologie na kostech medvědů (Ursus deningeri) z jeskyně „Za Hájovnou“, Javoříčský kras [Paleopathology on the bear bones (Ursus deningeri) from "Za Hájovnou” Cave, Javoříčko Karst, Moravia]. - Př́rodovědné studie Muzea Prostějovska, 8: 167-170. (in Czech)

Nývltová-Fišáková, M. (2007): Paleopathology on the bear bones (Ursus deningeri). - Scripta Facultatis Scientiarum Naturalium Universitatis Masarykianae Brunensis, 35: 168.

Rabeder, G. (1983): Neues von Höhlenbären. Zur Morphogenetik der Backenzähne. - Die Höhle, 34(2): 67-85.

Rabeder, G. (1989): Modus und Geschwindigkeit der Höhlenbären-Evolution. - Schriftenreihe des Vereins zur Verbreitung naturwissenschaftlicher Kenntnisse in Wien, 127: $105-126$.

Rabeder, G. (1999): Die Evolution des HöhlenbärenGebisses. - Mitteilung der Kommission für Quartärforschung der Österreichischen Akademie der Wissenschaften, 11: 1-102.

Rode, K. (1935): Untersuchungen über das Gebiß der Bären. - Monographien zur Geologie und Palaeontologie, ser. 2, 7: $1-162$.

Sabol, M. (2005a): Štruktúra medvedej populácie z jaskyne „Za Hájovnou“ (Morava, Česká republika) z hl'adiska zastúpenia pohlaví a vekových štádií: predbežné výsledky [Sex ratio and age structure of bears from the " $\mathrm{Za}$ Hájovnou" Cave (Moravia, Czech Republic): Preliminary results]. - Př́rodovědné studie Muzea Prostějovska, 8: 153-165. (in Slovak)

Sabol, M. (2005b): Bear assemblage from the Za Hájovnou Cave in Moravia (Czech Republic): sex ratio and age structure. - Abhandlungen der Naturhistorischen Gesellschaft Nürnberg, 45: 215-224.

Sabol, M. (2014): Basic population and taphonomic analysis of bear assemblages from Za Hájovnou Cave (Moravia, Czech Republic): a fossil record from 1987-2007. - Acta Musei Nationalis Pragae, Ser. B, Historia Naturalis, 70(1-2): 71-90.
Schreve, D. C., Bridgland, D. R. (2002): Correlation of English and German Middle Pleistocene fluvial sequences based on mammalian biostratigraphy. - Netherlands Journal of Geosciences, 81: 357-373.

Vöröš, D. (2013): Nové výzkumy savčí mikrofauny jeskyně Za Hájovnou (Javoříčský kras) [New research on mammal microfauna from the $\mathrm{Za}$ Hájovnou Cave (Javoříčko Karst)]; bachelor thesis. - MS, Ústav geologických věd, Př́rodovědecká fakulta Masarykovy univerzity: 1-30. Brno. (in Czech)

Wagner, J. (2003): Taxonomické určení nálezů rodu Ursus (Mammalia, Ursidae) z vybraných biharských lokalit České a Slovenské republiky [Taxonomical determination of bears (Ursus, Ursidae, Mammalia) from the selected localities of the Czech and Slovak Republic]; Diplomová práce. - MS, Ústav geologie a paleontologie, PřF UK: 1-133. Praha. (in Czech)

Wagner, J. (2005): Morfometrická charakteristika dentálního materiálu medvědů z jeskyně „Za Hájovnou“, Javoříčský kras [Morphometric characteristic of bear dental material from "Za Hájovnou” Cave, Javoříčko Karst, Moravia]. Př́rodovědné studie Muzea Prostějovska, 8: 109-142. (in Czech)

Wagner, J., Čermák, S. (2012): Revision of the early Middle Pleistocene bears (Ursidae, Mammalia) of Central Europe, with special respect to possible co-occurrence of spelaeoid and arctoid lineages. - Bulletin of Geosciences, 87: 461-496. http://dx.doi.org/10.3140/bull.geosci.1354

\section{Appendix 1}

\section{Measurements and indexes for particular teeth from Za Hájovnou Cave collected after 2004}

List of character abbreviations used in the tables:

BLTA - buccal length of talon(id); BLTR - buccal length of trigon(id); BLW - width sensu Driesch (1976); CH - Chdoba naděje; $d$ - right; DPR-ME - distance between apexes of Prd and Med; HE1 - End 1 height; HE2 - End 2 height; HME Me height; HPA - Pa height; HPR - Prd height; LANT length of anterior lobe; LE1 - End 1-complex length; LE2 End 2-complex length; LENC - End-complex length; LINL - lingual length; LLTA - lingual length of talonid; LLTR lingual length of trigon(id); LME - metacone length; LMEC - metacone-complex length; LPA - paracone length; LPAC - paracone-complex length; LPOST - length of posterior lobe; $\mathrm{s}$ - left; MAXL - maximal length; MAXW - maximal width; WCON - width of constriction; WCONM - minimal width of constriction; WANT - width of anterior lobe (across $\mathrm{Pa}$ ); WPOST - width of posterior lobe (across Me); WTA width of talon(id); WTR - width of trigonid.

index RELWCON $=($ WCON $/(($ WANT + WPOST $) / 2)) * 100$ for $\mathrm{M} 1$ and $(\mathrm{WCON} /((\mathrm{WTR}+\mathrm{WTA}) / 2))^{*} 100$ for $\mathrm{m} 1$ and $\mathrm{m} 2$. 
Tab. A1. Measurements and indexes for $\mathbf{P 4}$.

\begin{tabular}{|c|c|c|c|c|c|c|c|c|c|c|}
\hline 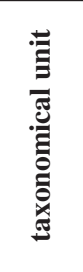 & P4 & s/d & $\sum_{i}^{x}$ & $\frac{3}{x}$ & $\begin{array}{l}z \\
0 \\
Z \\
z\end{array}$ & 音 & $\widehat{\underline{\Xi}}$ & 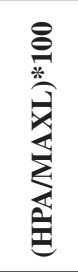 & 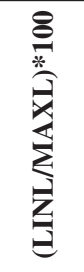 & 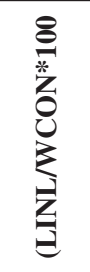 \\
\hline$\overline{\text { MIS 9 }}$ & $2007 / 11$ & $\mathrm{~s}$ & 19.1 & 14.2 & 11.7 & 15.7 & $\overline{-}$ & - & 82.20 & 134.19 \\
\hline \multirow{10}{*}{$\begin{array}{l}\exists \\
\stackrel{\mathscr{N}}{E}\end{array}$} & $2006 / 2$ & $\mathrm{~d}$ & 16.8 & 12.2 & 10.4 & 12.3 & - & - & 73.21 & 118.27 \\
\hline & $2009 / 28$ & $\mathrm{~s}$ & 17.3 & 13.1 & 12.3 & 14.6 & - & - & 84.39 & 118.70 \\
\hline & $2009 / 76$ & $\mathrm{~d}$ & 18.2 & 12.7 & 11.3 & 14.2 & - & - & 78.02 & 125.66 \\
\hline & $2010 / 10$ & $\mathrm{~s}$ & 18.4 & 13.0 & 11.0 & 14.6 & - & - & 79.35 & 132.73 \\
\hline & $2010 / 11$ & $\mathrm{~d}$ & 18.6 & 12.9 & 11.5 & 14.3 & 10.6 & 56.99 & 76.88 & 124.35 \\
\hline & $2012 / 7$ & $\mathrm{~d}$ & 19.2 & 13.5 & 11.3 & 14.8 & 11.6 & 60.42 & 77.08 & 130.97 \\
\hline & $2012 / 8$ & $\mathrm{~s}$ & 18.7 & 12.4 & 10.7 & 14.3 & 10.2 & 54.66 & 76.63 & 133.64 \\
\hline & $2012 / 9$ & $\mathrm{~d}$ & 18.7 & 12.5 & 11.6 & 15.2 & 10.9 & 58.29 & 81.28 & 131.03 \\
\hline & Ok 139175 & $\mathrm{~s}$ & 20.0 & 13.7 & - & - & - & - & - & - \\
\hline & Ok 139216 & $\mathrm{~d}$ & 16.4 & 13.1 & 11.7 & 14.8 & 9.6 & 58.54 & 90.24 & 126.50 \\
\hline
\end{tabular}

Tab. A2. Measurements and indexes for M1.

\begin{tabular}{|c|c|c|c|c|c|c|c|c|c|c|c|c|c|c|c|c|c|c|c|c|c|c|}
\hline 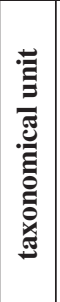 & M1 & s/d & $\frac{D}{\Sigma}$ & $\frac{3}{10}$ & $\frac{1}{2}$ & $\begin{array}{l}5 \\
0 \\
0 \\
3\end{array}$ & $\begin{array}{l}z \\
0 \\
0 \\
z\end{array}$ & 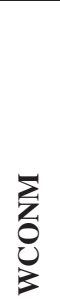 & 安 & 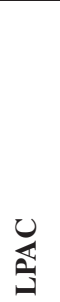 & $\begin{array}{l}5 \\
0 \\
\vdots \\
\vdots\end{array}$ & $\sum_{\text {导 }}^{\text {孚 }}$ & $\widehat{\underline{\Xi}}$ & $\sum^{\text {II }}$ & 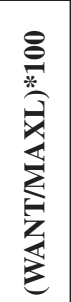 & 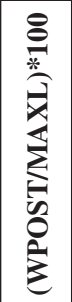 & 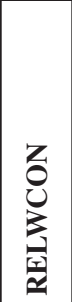 & 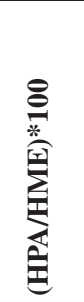 & 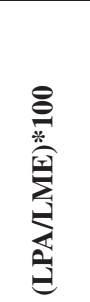 & 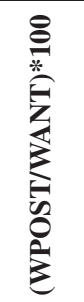 & 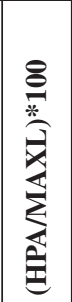 & 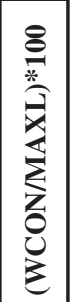 \\
\hline \multirow{22}{*}{$\begin{array}{l}= \\
\Omega \\
\Sigma\end{array}$} & $06 / 3$ & $\mathrm{~s}$ & 27.4 & 19.5 & 19.0 & 19.5 & 18.4 & 18.1 & 13.7 & 10.5 & 13.1 & 9.8 & - & - & 69.34 & \begin{tabular}{|l|}
71.17 \\
\end{tabular} & 95.58 & - & 107.14 & 102.63 & - & 67.15 \\
\hline & $2009 / 13$ & $\mathrm{~s}$ & 28.0 & 19.9 & - & 19.6 & - & - & 13.8 & 10.7 & 13.5 & 9.9 & 10.1 & 10.3 & - & 70.00 & - & 98.06 & 08.08 & - & 36.07 & - \\
\hline & $009 / 14$ & & & 19.4 & 18.6 & 19.3 & 17.7 & 17.5 & 13.3 & 10.1 & 13.8 & 9.5 & 11.7 & - & 69.14 & 71.75 & \begin{tabular}{|l|}
93.40 \\
\end{tabular} & & 06.32 & 03.76 & 43.49 & 65.80 \\
\hline & $2009 / 15$ & & 26.0 & 19.7 & 18.7 & 19.7 & 17.9 & 17.6 & 13.0 & 11.1 & 13.0 & 0.0 & 10.8 & 10.7 & 71.92 & 75.77 & 93.23 & & 111.00 & 05.35 & 41.54 & 68.85 \\
\hline & 2009/16 & $\mathrm{d}$ & 27.5 & 19.3 & 17.1 & 19.2 & 17.3 & 17.1 & 13.8 & 10.8 & 13.0 & 9.8 & - & - & 62.18 & 69.82 & 95.32 & & 110.20 & 112.28 & - & 62.91 \\
\hline & 2009/17 & $\mathrm{s}$ & 30.0 & 21.5 & 20.1 & 21.5 & 20.2 & 20.2 & 13.1 & 10.9 & 13.4 & 10.2 & 11.8 & 11.3 & 67.00 & - & - & 104.42 & 106.86 & - & 39.33 & 67.33 \\
\hline & $2009 / 18$ & & 28.3 & 19.8 & 19.8 & 19.6 & 18.9 & 18.7 & 13.7 & 10.9 & 13.8 & 9.9 & - & - & \begin{tabular}{|l|}
69.96 \\
\end{tabular} & 69.26 & 95.94 & & 110.10 & 98.99 & - & 66.78 \\
\hline & 2009/19 & & 27.4 & 19.8 & 19.1 & 19.2 & 18.0 & 18.1 & 11.9 & 9.8 & 13.0 & 9.2 & - & - & 69.71 & 70.07 & 93.99 & & 106.52 & $\overline{00.52}$ & - & 65.6 \\
\hline & $2009 / 78 \mathrm{a}$ & $\mathrm{d}$ & 25.8 & 18.9 & 17.6 & 19.1 & 16.9 & 17.1 & 12.5 & 10.4 & 12.1 & 8.8 & - & - & 68.22 & 74.03 & 92.10 & - & 118.18 & 108.52 & - & 65.50 \\
\hline & 2009/79 & $\mathrm{d}$ & 28.2 & 19.5 & 18.5 & 19.4 & 18.1 & 17.9 & 13.7 & 10.9 & 13.4 & 9.3 & 10.8 & 10.4 & 65.60 & 68.79 & 95.51 & 103.85 & 117.20 & 104.86 & 38.30 & 64.18 \\
\hline & $2010 / 15$ & $\mathrm{~s}$ & 25.8 & 18.0 & 17.4 & 17.8 & 17.0 & 16.7 & 11.6 & 8.6 & 12.3 & 9.2 & 10.3 & 9.9 & 67.44 & 68.99 & 96.59 & 104.04 & 93.48 & 102.30 & 39.92 & 65.89 \\
\hline & $2010 / 21$ & & 27.5 & 18.8 & & 18.5 & 17.6 & 17.6 & 13.6 & 11.7 & 13.0 & 9.5 & - & - & - & 67.27 & - & & 23.16 & 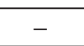 & - & 64.00 \\
\hline & $2012 / 6$ & $\mathrm{~d}$ & 25.0 & 17.7 & 17.0 & 17.7 & 16.6 & 16.4 & 11.8 & 9.5 & 12.4 & 9.3 & 10.2 & 9.9 & 68.00 & 70.80 & \begin{tabular}{|l|}
95.68 \\
\end{tabular} & 03.03 & 102.15 & 04.12 & 40.80 & 66.40 \\
\hline & $2012 / 14$ & $\mathrm{~s}$ & 26.8 & 19.0 & 18.7 & 19.0 & 17.2 & 17.0 & 13.0 & 10.6 & 13.8 & 10.5 & 10.3 & 10.4 & 69.78 & 70.90 & 91.25 & 99.04 & 100.95 & 101.60 & 38.43 & 64.18 \\
\hline & Ok 139166 & d & 26.1 & 17.5 & 16.9 & 17.6 & 16.1 & 16.1 & 11.5 & 8.7 & 12.2 & 8.3 & - & - & 64.75 & 67.43 & 93.33 & - & 104.82 & 104.14 & - & 61.69 \\
\hline & Ok 139184 & $\mathrm{~s}$ & 26.3 & 18.7 & 18.2 & 18.6 & 17.4 & 17.4 & 13.5 & 11.1 & 12.7 & 9.6 & 10.9 & - & 69.20 & 70.72 & 94.57 & - & 115.63 & 102.20 & 41.44 & 66.16 \\
\hline & Ok 139181 & $\mathrm{~d}$ & 23.0 & 16.9 & 16.5 & 17.0 & 15.2 & 15.1 & 11.1 & 9.2 & 11.2 & 8.2 & 9.2 & 9.3 & 71.74 & 73.91 & 90.75 & 98.92 & 112.20 & 103.03 & 40.00 & 66.09 \\
\hline & Ok 139180 & $\mathrm{~d}$ & 26.5 & 18.0 & 17.3 & 18.0 & 16.9 & 16.6 & 12.0 & 9.3 & 12.3 & 8.7 & 10.0 & 9.5 & 65.28 & 67.92 & 95.75 & 105.26 & 106.90 & 104.05 & 37.74 & 63.77 \\
\hline & Ok 139182 & $\mathrm{~s}$ & 26.0 & 18.2 & 17.2 & 18.3 & 16.8 & 16.1 & 12.9 & 10.2 & 12.5 & 9.5 & - & - & 66.15 & 70.38 & 94.65 & - & 107.37 & 106.40 & - & 64.62 \\
\hline & Ok 139183 & $\mathrm{~d}$ & - & 18.3 & 17.0 & 18.5 & 16.4 & 16.3 & 12.9 & 9.9 & 12.7 & 9.1 & - & - & - & - & \begin{tabular}{|l|}
92.39 \\
\end{tabular} & - & 108.79 & 108.82 & - & - \\
\hline & & d & - & - & - & - & 16.5 & - & 12.6 & 9.9 & - & - & 10.0 & & - & - & - & - & 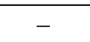 & 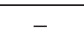 & - & - \\
\hline & & $\mathrm{d}$ & - & 17.5 & 16.9 & 17.6 & 15.9 & & - & 10.7 & 11.2 & 9.4 & - & - & - & - & 92.17 & - & 113.83 & 04.14 & - & - \\
\hline $\mathbf{H}$ & $2006 / 17$ & $\mathrm{~s}$ & - & 19.0 & 18.2 & 18.7 & 17.9 & 17.3 & - & 10.2 & 12.1 & 8.8 & 9.6 & 9.5 & - & - & 97.02 & 101.05 & 115.91 & 102.75 & - & - \\
\hline
\end{tabular}


Tab. A3. Measurements and indexes for M2.

\begin{tabular}{|c|c|c|c|c|c|c|c|c|c|c|c|c|c|c|c|c|c|c|c|}
\hline 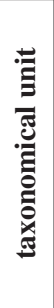 & M2 & s/d & 齐 & $\frac{5}{3}$ & $\begin{array}{l}5 \\
0 \\
0 \\
3\end{array}$ & $\begin{array}{l}z \\
0 \\
\text { Z } \\
3\end{array}$ & $\frac{3}{3}$ & 点 & 点 & 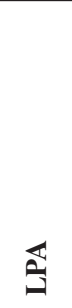 & فِ & $\sum_{\text {I }}^{|c|}$ & 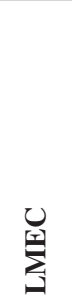 & 気 & $\sum^{\text {될 }}$ & $\frac{8}{\stackrel{*}{0}}$ & 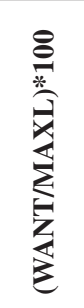 & 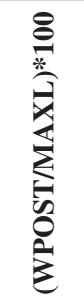 & 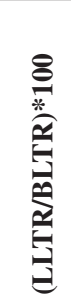 \\
\hline \multirow{28}{*}{$\begin{array}{l}\exists \\
\stackrel{\mathscr{\Omega}}{\Sigma}\end{array}$} & $2006 / 4$ & $\mathrm{~s}$ & - & 22.4 & - & - & - & - & - & 7.8 & 12.7 & - & - & - & - & - & $\overline{-}$ & - & - \\
\hline & $2006 / 7$ & $\mathrm{~d}$ & 40.1 & 20.3 & 19.1 & 19.0 & 16.5 & 23.0 & 16.5 & 9.2 & 11.7 & 6.7 & 9.9 & 10.4 & & 57.36 & 50.62 & 47.63 & 71.74 \\
\hline & $2006 / 8$ & d & 41.2 & 20.3 & 20.5 & 20.0 & 18.6 & 23.8 & 16.0 & 10.3 & 11.8 & 7.1 & 10.0 & 10.8 & 9.9 & 57.77 & 49.27 & 49.76 & 67.23 \\
\hline & $2006 / 9$ & $\mathrm{~s}$ & 41.6 & 20.7 & 20.3 & 19.3 & 17.7 & 26.0 & - & - & - & - & 13.1 & - & - & 62.50 & 49.76 & 48.80 & - \\
\hline & $2009 / 20$ & $\mathrm{~d}$ & 39.5 & 21.2 & 20.6 & 20.0 & 15.4 & 25.6 & 17.9 & 10.5 & 12.7 & 8.2 & 11.9 & 11.3 & 11.1 & 64.81 & 53.67 & 52.15 & 69.92 \\
\hline & $2009 / 21$ & $\mathrm{~s}$ & 47.2 & 23.8 & 23.0 & 22.7 & 18.6 & 28.3 & 19.6 & 7.4 & 15.4 & 7. & 12.4 & 11.2 & 10.8 & 59.96 & 50.42 & 48.73 & 69.26 \\
\hline & $2009 / 22$ & $\mathrm{~d}$ & 38.8 & 20.9 & 19.7 & 20.6 & 14.6 & 23.7 & 18.3 & 9.4 & 10.9 & 7. & 11.3 & 10.1 & 9.4 & 61.08 & 53.87 & 50.77 & 77.22 \\
\hline & $2009 / 23$ & $\mathrm{~s}$ & 44.1 & 23.0 & 20.6 & 21.3 & 17.5 & 27.4 & 18.5 & 10.1 & 12.9 & 7.6 & 12.3 & - & - & 62.13 & 52.15 & 46.71 & 67.52 \\
\hline & $2009 / 24$ & $\mathrm{~d}$ & 41.5 & 20.9 & 21.3 & 21.4 & 15.8 & 25.7 & 19.6 & - & 12.6 & 5.5 & 12.3 & - & - & 61.93 & 50.36 & 51.33 & 76.26 \\
\hline & $2009 / 25$ & $\mathrm{~d}$ & 41.8 & 21.8 & 20.5 & 20.3 & 16.6 & 25.1 & 15.4 & 9.3 & 12 . & 7. & & - & - & 60.05 & 52.15 & 49.04 & 61.35 \\
\hline & $2009 / 26$ & $\mathrm{~s}$ & 47.3 & 22.7 & 22.6 & 21.7 & 19.4 & 26.5 & 18.9 & 8.9 & 12.7 & 5.8 & 11.3 & - & - & 56.03 & 47.99 & 47.78 & 71.32 \\
\hline & $2009 / 27$ & $\mathrm{~d}$ & - & 21.0 & - & 20.5 & 18.7 & 25.9 & 20.1 & 6.9 & 13.4 & - & 10.8 & - & - & - & - & - & 77.64 \\
\hline & $2009 / 77$ & $\mathrm{~s}$ & 43.8 & 21.3 & 20.7 & 21.1 & 17.6 & 25.3 & 21.2 & - & 13.3 & 7.8 & 10.3 & - & - & 57.76 & 48.63 & 47.26 & 83.79 \\
\hline & $2009 / 78 b$ & $\mathrm{~d}$ & 42.5 & 22.5 & 20.7 & 20.9 & 18.7 & 25.1 & 18.5 & - & 12.5 & 7. & 10.7 & - & - & 59.06 & 52.94 & 48.71 & 73.71 \\
\hline & $2010 / 6$ & $\mathrm{~s}$ & 41.3 & 22.3 & 20.2 & 20.5 & 15.5 & 23.7 & 19.5 & 10.5 & 12.4 & 5.9 & 10.1 & 10.3 & 10.1 & 57.38 & 54.00 & 48.91 & 82.28 \\
\hline & $2010 / 7$ & $\mathrm{~d}$ & 42.1 & - & 19.9 & 19.2 & 19.1 & 23.6 & 16.5 & 11.6 & 13.5 & - & 9.2 & - & - & 56.06 & - & 47.27 & 69.92 \\
\hline & $2010 / 8$ & $\mathrm{~d}$ & 44.6 & - & - & - & 17.4 & 24.9 & 19.3 & 12.1 & 14.1 & 9.5 & 11.1 & 11.2 & 10.7 & 55.83 & - & - & 77.51 \\
\hline & $2010 / 9$ & $\mathrm{~s}$ & - & 20.3 & 19.4 & 19.2 & 15.9 & 23.0 & 24.1 & 10.8 & - & 8. & 10.2 & 9.3 & 8.8 & - & - & - & 104.78 \\
\hline & $2012 / 4$ & $\mathrm{~s}$ & 38.8 & 18.0 & 18.5 & 17.6 & 15.9 & 22.3 & 14.8 & 10.0 & 12.2 & 7.5 & 10.2 & 9.1 & 8.2 & 57.47 & 46.39 & 47.68 & 66.37 \\
\hline & $2012 / 5$ & $\mathrm{~s}$ & - & 22.3 & - & 21.7 & - & - & - & 9.7 & 14.2 & - & - & 9.9 & - & - & - & - & - \\
\hline & $2012 / 13$ & $\mathrm{~s}$ & 45.2 & - & 22.3 & 22.0 & 18.7 & 25.7 & 19.3 & 11.5 & 12.4 & 6.3 & 12.1 & 10.7 & 10.6 & 56.86 & - & 49.34 & 75.10 \\
\hline & $2012 / 19$ & $\mathrm{~s}$ & - & 22.9 & 21.1 & 21.4 & - & 26.8 & 20.6 & - & - & - & 12.1 & - & - & - & - & - & 76.87 \\
\hline & Ok 139177 & $\mathrm{~s}$ & 45.0 & 22.2 & 20.6 & 20.6 & 16.9 & 25.8 & 20.0 & 9.9 & - & 8.1 & 11.2 & - & - & 57.33 & 49.33 & 45.78 & 77.52 \\
\hline & Ok 139179 & $\mathrm{~d}$ & 39.6 & 21.3 & 19.3 & 19.9 & 15.7 & 23.8 & 16.2 & 10.3 & 12.5 & 7.0 & 10.0 & - & - & 60.10 & 53.79 & 48.74 & 68.07 \\
\hline & Ok 139178 & $\mathrm{~d}$ & 38.3 & 20.3 & 19.4 & 19.3 & 16.9 & 23.5 & 15.8 & - & - & - & 9.7 & - & - & 61.36 & 53.00 & 50.65 & 67.23 \\
\hline & Ok 139217 & $\mathrm{~d}$ & - & - & 17.8 & - & 17.1 & - & - & - & - & - & - & - & - & - & - & - & - \\
\hline & Ok 138985 & $\mathrm{~d}$ & 38.7 & 19.3 & 20.2 & 19.3 & 16.3 & 22.6 & 15.9 & 9.1 & 11.5 & 6.4 & 9.6 & 10.0 & 9.8 & 58.40 & 49.87 & 52.20 & 70.35 \\
\hline & \begin{tabular}{|l|} 
Ok 138984 \\
\end{tabular} & $\mathrm{~s}$ & - & - & 18.4 & 19.2 & - & - & - & - & - & 4.7 & 9.6 & - & - & - & - & - & - \\
\hline $\mathrm{CH}$ & 2006/18 & $\mathrm{s}$ & 39.9 & 20.4 & 20.1 & 19.4 & 16.3 & 23.8 & - & - & 11.3 & 6.4 & 10.3 & - & - & 59.65 & 51.13 & 50.38 & - \\
\hline
\end{tabular}

Tab. A4. Measurements and indexes for p4.

\begin{tabular}{|c|c|c|c|c|c|c|}
\hline 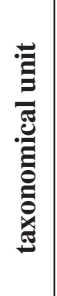 & p4 & $\mathrm{s} / \mathrm{d}$ & $\underset{z}{\bar{x}}$ & $\frac{x}{\sum}$ & 角 & 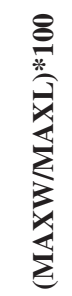 \\
\hline \multirow{9}{*}{$\begin{array}{l}\exists \\
\frac{\mathscr{O}}{\sum}\end{array}$} & $2006 / 5$ & $\mathrm{~d}$ & 13.2 & 8.4 & 8.6 & $\overline{63.64}$ \\
\hline & $2009 / 29$ & $\mathrm{~s}$ & 15.6 & 11.0 & 10.0 & 70.51 \\
\hline & $2009 / 30$ & $\mathrm{~s}$ & 15.0 & 9.5 & - & 63.33 \\
\hline & $2009 / 31$ & $\mathrm{~s}$ & 12.2 & 8.5 & 8.0 & 69.67 \\
\hline & $2009 / 35 c$ & $\mathrm{~s}$ & 14.4 & 8.6 & - & 59.72 \\
\hline & $2010 / 12 d$ & $\mathrm{~s}$ & 13.4 & - & - & - \\
\hline & $2012 / 10$ & $\mathrm{~s}$ & 13.8 & 8.3 & 8.8 & 60.14 \\
\hline & Ok 139249 & $\mathrm{~s}$ & 14.9 & - & 9.0 & - \\
\hline & Ok 138990 & $\mathrm{~s}$ & - & 7.9 & 7.4 & - \\
\hline $\mathbf{C H}$ & Ok 139026d & $\mathrm{s}$ & 14.0 & 8.1 & 7.8 & 57.86 \\
\hline
\end{tabular}




\begin{tabular}{|c|c|c|c|c|c|c|c|c|c|c|c|c|c|c|c|c|c|c|c|c|c|c|c|}
\hline$\Omega$ & \multicolumn{22}{|c|}{ MIS 11} & taxonomical unit \\
\hline 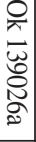 & 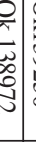 & 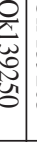 & 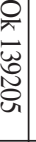 & 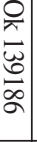 & 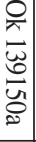 & 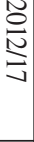 & $\begin{array}{l}\frac{N}{\frac{0}{N}} \\
\frac{N}{\sigma}\end{array}$ & $\begin{array}{l}\frac{\tilde{O}}{\stackrel{N}{S}} \\
\text { un }\end{array}$ & $\begin{array}{l}\stackrel{N}{\stackrel{N}{N}} \\
=\end{array}$ & 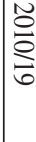 & $\underset{\infty}{\infty}$ & ఠ) & 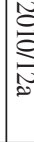 & 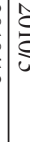 & 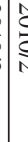 & & 5 & 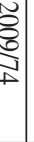 & 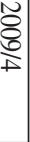 & 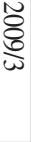 & & 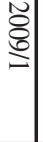 & $\Xi$ \\
\hline$\infty$ & s & 2 & $\infty$ & $\infty$ & 2 & $=$ & $\infty$ & 2 & en & e & n & $=$ & os & r & 0 & s & 25 & e & $\infty$ & a & is & $\infty$ & 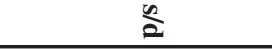 \\
\hline 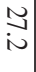 & I & । & । & 1 & ي્ّ & 1 & 1 & $\underset{\infty}{N}$ & 己. & $\stackrel{N}{\stackrel{2}{+}}$ & $\stackrel{N}{\sim}$ & $\infty$ & ت & 1 & 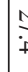 & & o. & 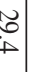 & $\begin{array}{l}\text { 崩 } \\
\text { iv }\end{array}$ & సু & $\begin{array}{l}\vec{y} \\
0\end{array}$ & 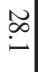 & MAXL \\
\hline$\vec{\sigma}$ & ' & । & । & 1 & $\overrightarrow{6}$ & 1 & 1 & $\vec{\omega}$ & $\underset{+}{\not}$ & $\stackrel{2}{*}$ & $\exists$ & 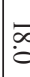 & 1 & । & 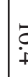 & $\vec{s}$ & b. & है & $\overrightarrow{0}$ & $\stackrel{a}{y}$ & $\underset{\infty}{\vec{\infty}}$ & $\overrightarrow{0}$ & BLTR \\
\hline$\vec{v}$ & । & । & । & I & $\underset{\sim}{\vec{v}}$ & & $\nsubseteq$ & $\begin{array}{l}\vec{u} \\
\infty\end{array}$ & $\overrightarrow{0}$ & $\stackrel{+}{a}$ & $\bar{c}$ & 我 & i & 1 & ' & 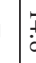 & $\vec{\infty}$ & $\bar{\phi}$ & $\vec{a}$ & $\underset{\infty}{+\infty}$ & ज̆ & ज̆ & LLTR \\
\hline$\underset{\omega}{\vec{\omega}}$ & $0:$ & is & । & 잉 & $\begin{array}{l}\overrightarrow{0} \\
\infty\end{array}$ & & 1 & i & $\bar{N}$ & a & $\infty$ & 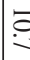 & 1 & 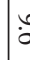 & a & & & 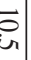 & 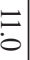 & $\underset{\infty}{0}$ & : & 잉 & BLTA \\
\hline$\stackrel{\sim}{-}$ & $\bar{\omega}$ & : & I & $\begin{array}{c}\vec{w} \\
\dot{a}\end{array}$ & $\stackrel{ }{\sim}$ & & 1 & $\bar{\sigma}$ & $\vec{\omega}$ & 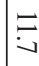 & $\bar{i}$ & $\stackrel{?}{9}$ & $\sigma$ & $?$ & & 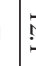 & & $\overrightarrow{\mathrm{v}}$ & $\vec{w}$ & $\bar{n}$ & $\begin{array}{l}\vec{N} \\
\stackrel{N}{N}\end{array}$ & $\bar{N}$ & LLTA \\
\hline$\stackrel{\vec{\circ}}{\stackrel{1}{*}}$ & 0 & $\begin{array}{c}\infty \\
i \\
i\end{array}$ & I & $\overrightarrow{u_{n}}$ & $\Xi$ & 1 & 1 & 웅 & $\stackrel{N}{\circ}$ & $\stackrel{\bullet}{\sim}$ & $\infty$ & वे & 1 & is & 3 & & 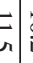 & $\begin{array}{l}\overrightarrow{0} \\
\mathrm{~N}\end{array}$ & $\vec{w}$ & in & å & i & LENC \\
\hline 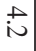 & $\stackrel{p}{\oplus}$ & $+\infty$ & & : & $\because$ & & 1 & $\stackrel{t}{\mapsto}$ & $\ddot{0}$ & $\omega$ & $\ddot{i}$ & $\dot{0}$ & 1 & i & & $\begin{array}{l}0 \\
0.9\end{array}$ & rats & $\omega$ & $\ddot{i}$ & in & in & $+\infty$ & LE1C \\
\hline 2 & $\infty$ & $\begin{array}{r}* \\
0\end{array}$ & । & וּ & $\vec{u}$ & & 1 & $\because$ & iे & à & $\ddot{\infty}$ & 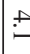 & I & $\because$ & t & 今) & h్ & 6 & $\dot{a}$ & 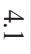 & $\dot{i n}$ & $\mid$ & LE2C \\
\hline$\stackrel{\circ}{\bullet}$ & । & । & । & । & in & 1 & कू & 1 & $\bar{\omega}$ & $\stackrel{\bullet}{\sim}$ & $\Xi$ & $\stackrel{\infty}{\circ}$ & $\%$ & 1 & 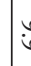 & $:$ & । & $=$ & $\underset{\infty}{\infty}$ & $\overline{0}$ & $\overbrace{\infty}^{\circ}$ & $=$ & WTR \\
\hline $\begin{array}{c}\vec{\infty} \\
\infty\end{array}$ & $\overrightarrow{\mathrm{u}}$ & $\overline{6}$ & $\begin{array}{l}\vec{w} \\
\sigma\end{array}$ & $\vec{\omega}$ & $\stackrel{\sim}{\sim}$ & $\stackrel{\vec{P}}{+}$ & 1 & $\vec{\omega}$ & $\bar{o}$ & 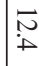 & $\vec{w}$ & o & 7 & $?$ & 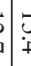 & $\overrightarrow{0}$ & $\vec{\omega}$ & $\vec{\omega}$ & $\vec{a}$ & $\vec{\omega}$ & $\stackrel{n}{\infty}$ & 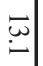 & WTA \\
\hline$\stackrel{\vec{\perp}}{+}$ & $\begin{array}{l}5 \\
\infty \\
\infty\end{array}$ & $\begin{array}{l}\overrightarrow{0} \\
i\end{array}$ & $\Xi$ & $\overrightarrow{u_{i}}$ & 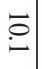 & $\overrightarrow{6}$ & 1 & 1 & $\stackrel{i}{+}$ & ${ }_{i}$ & $\stackrel{N}{i}$ & $\ddot{\infty}$ & O & 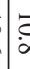 & & & 5 & $=$ & $\stackrel{\sim}{N}$ & $\underset{\infty}{\vec{\infty}}$ & $\vec{\sigma}$ & $\stackrel{\square}{\oplus}$ & WCON \\
\hline 1 & $\infty$ & 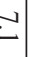 & 1 & 1 & 1 & 1 & 1 & 1 & $\because$ & $\overrightarrow{0}$ & $\stackrel{\infty}{i}$ & $\ddot{\sigma}$ & 1 & $\dot{\theta}$ & & 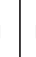 & 1 & $\infty$ & । & । & $\infty$ & it & HE1 \\
\hline 1 & s. & 2 & 1 & 1 & 1 & । & 1 & 1 & $\infty$ & 9 & $\stackrel{\infty}{\rightarrow}$ & $\stackrel{9}{9}$ & 1 & $i$ & 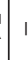 & 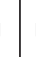 & 3 & 文 & । & जे & in & is & HE2 \\
\hline 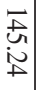 & 8 & \begin{tabular}{|l|l|}
$\overrightarrow{1}$ \\
$\dot{0}$ \\
$\infty$
\end{tabular} & & $\begin{array}{l}2 \\
\vdots \\
\vdots\end{array}$ & $\mid \begin{array}{l}\vec{\omega} \\
\vec{\omega} \\
\infty\end{array}$ & & 1 & $\begin{array}{l}\text { N } \\
\text { 㭊 }\end{array}$ & 妾 & $w_{\omega}^{\infty}$ & $\stackrel{\infty}{\sim}$ & $\stackrel{?}{?}$ & 1 & 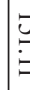 & 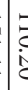 & & 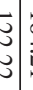 & 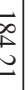 & $\begin{array}{l}\vec{t} \\
\vec{u} \\
\vec{u}\end{array}$ & 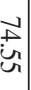 & $\begin{array}{l}\infty \\
\dot{\downarrow} \\
\dot{\phi}\end{array}$ & 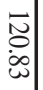 & $($ LE2C/LE1C)*100 \\
\hline 㞾 & I & । & I & 1 & $\begin{array}{l}\stackrel{\omega}{ \pm} \\
\vdots \\
=\end{array}$ & & । & 1 & $\begin{array}{l}\tilde{\omega} \\
\dot{w}\end{array}$ & $\stackrel{\sim}{\vec{\perp}}$ & $\begin{array}{l}+ \\
\dot{0} \\
+\end{array}$ & 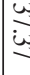 & 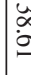 & 1 & 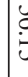 & $\underline{n}$ & I & ڤు & 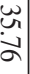 & $\begin{array}{l}\text { w } \\
\text { ळ̊ }\end{array}$ & \begin{tabular}{l}
$w$ \\
$\infty$ \\
\hdashline \\
$=$ \\
$=$
\end{tabular} & 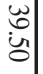 & (WTR/MAXL)*100 \\
\hline $\begin{array}{l}\overrightarrow{0} \\
\dot{8}\end{array}$ & I & । & 1 & 1 & $\begin{array}{l}\overrightarrow{0} \\
\dot{\imath}\end{array}$ & I & । & $\begin{array}{l}\stackrel{+}{a} \\
\stackrel{a}{\sigma}\end{array}$ & $\begin{array}{l}+ \\
\infty \\
\dot{w} \\
+1\end{array}$ & $\begin{array}{l}+ \\
\dot{6}\end{array}$ & $\underset{w}{\infty}$ & $\stackrel{+}{\nexists}$ & 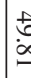 & 1 & : & $\begin{array}{l}\vec{b} \\
0 \\
0\end{array}$ & & $\begin{array}{l}\hat{n} \\
\hat{\imath}\end{array}$ & $\begin{array}{c}\vec{\infty} \\
\dot{w} \\
\not\end{array}$ & 岁 & 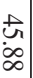 & $\begin{array}{l}\text { के } \\
\text {.े }\end{array}$ & $($ WTA/MAXL)*100 \\
\hline 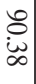 & ' & । & । & 1 & 号 & I & 1 & 1 & $\stackrel{\bullet}{\stackrel{\omega}{\omega}}$ & $\stackrel{\circ}{=}$ & 我 & $\bar{\Xi}$ & 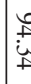 & 1 & & $\begin{array}{l}0 \\
0 \\
0 \\
\end{array}$ & & \begin{tabular}{|l}
3 \\
3 \\
3 \\
\end{tabular} & $\begin{array}{c}\infty \\
\infty \\
i \\
\end{array}$ & 岕 & :ొ & ज्ञ & $(\mathrm{WTR} / \mathrm{WCON}) * 100$ \\
\hline $\begin{array}{l}\text { U్ } \\
\dot{\sigma}\end{array}$ & & । & 1 & 1 & $\begin{array}{l}8 \\
8 \\
0 \\
0 \\
0\end{array}$ & । & 1 & I & $\stackrel{\text { }}{\rightleftarrows}$ & 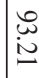 & li & $\mid \begin{array}{l}\infty \\
0 \\
i \\
i\end{array}$ & 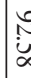 & & 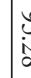 & $\begin{array}{l}0 \\
0 \\
0 \\
0 \\
0\end{array}$ & & 8 & ฉి & 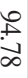 & 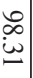 & 总 & RELWCON \\
\hline $\begin{array}{ll}\text { un } \\
\stackrel{u}{n}\end{array}$ & I & । & 1 & 1 & $\begin{array}{l}U_{\omega} \\
\stackrel{\omega}{N} \\
\end{array}$ & । & 1 & $\begin{array}{l}\mathscr{n} \\
\infty \\
\omega\end{array}$ & 峁 & $\ddot{u}$ & 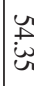 & $\infty$ & $\breve{.}$ & 1 & I & 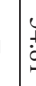 & & 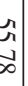 & 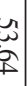 & فे & 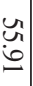 & $\mid \begin{array}{l}\text { : } \\
\dot{\infty}\end{array}$ & $($ LLTR/MAXL)*100 \\
\hline I & $\stackrel{N}{N}$ & 童 & & 1 & 1 & 1 & 1 & I & 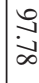 & 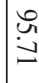 & & $\therefore$ & & f & & & & $\frac{0}{6}$ & । & । & & $\begin{array}{l}\text { हे } \\
\dot{8}\end{array}$ & $($ HE2/HE1)*100 \\
\hline
\end{tabular}




\begin{tabular}{|c|c|c|c|c|c|c|c|c|c|c|c|c|c|c|c|c|c|c|c|c|c|c|c|c|}
\hline \multicolumn{3}{|c|}{$\cong$} & \multicolumn{20}{|c|}{ MIS 11} & \multirow{2}{*}{ 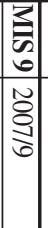 } & \multirow[t]{2}{*}{ taxonomical unit } \\
\hline 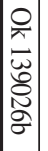 & 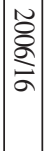 & & 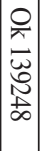 & 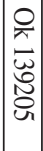 & 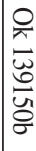 & $\frac{\stackrel{N}{\circ}}{\frac{N}{N}}$ & $\stackrel{\stackrel{ }{0}}{\stackrel{N}{=}}$ & 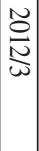 & $\frac{\tilde{N}}{\frac{N}{N}}$ & $\frac{\tilde{O}}{\stackrel{0}{0}}$ & 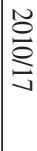 & 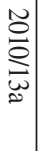 & 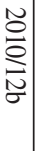 & 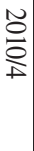 & 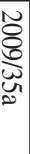 & 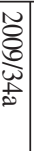 & 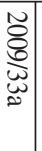 & 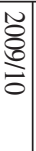 & 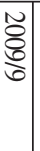 & 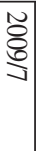 & 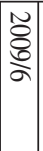 & 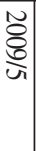 & & \\
\hline is & $=$ & $\infty$ & $\infty$ & $\infty$ & a & 2 & in & $=$ & e & $\infty$ & in & $\infty$ & $\infty$ & $\infty$ & n & $\infty$ & $\infty$ & 2 & a & $=$ & $\infty$ & $\infty$ & $=$ & $\frac{n}{2}$ \\
\hline$\stackrel{\sim}{\Omega}$ & $\mid \stackrel{\omega}{\sim}$ & $\begin{array}{l}1 \\
0 \\
0\end{array}$ & $\begin{array}{c}1 \\
\dot{0} \\
\infty\end{array}$ & $\underset{N}{N}$ & $\begin{array}{l}\tilde{u} \\
\ddot{u}\end{array}$ & $\underset{\substack{\infty \\
v}}{ }$ & $\underset{i}{\stackrel{\omega}{\sim}}$ & 1 & $\begin{array}{l}\text { D } \\
\text { in }\end{array}$ & $\begin{array}{l}\infty \\
\infty \\
\text { w }\end{array}$ & $\stackrel{\tilde{\omega}}{\tilde{\omega}}$ & $\begin{array}{l}\vec{e} \\
\dot{\omega}\end{array}$ & $\stackrel{\stackrel{p}{ \pm}}{=}$ & ب. & I & $\stackrel{\sim}{\sim}$ & 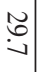 & $\stackrel{-1}{0}$ & 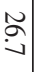 & 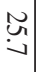 & $\begin{array}{l}2 \\
2 \\
\alpha\end{array}$ & $\begin{array}{l}N \\
\infty \\
\infty\end{array}$ & $\mathbb{0}$ & MAXL \\
\hline$\overline{0}$ & $\left(\begin{array}{l}6 \\
0\end{array}\right.$ & $\left|\begin{array}{l}\infty \\
\dot{u}\end{array}\right|$ & $\vec{\infty}$ & $\bar{\alpha}$ & $\ddot{v}$ & $\stackrel{\sim}{\sim}$ & $\begin{array}{l}\infty \\
\infty\end{array}$ & $\vec{w}$ & $\vec{\nabla}$ & $\underset{\infty}{-}$ & $\begin{array}{c}\bar{c} \\
\infty\end{array}$ & $\begin{array}{l}\text { ज } \\
\text { in }\end{array}$ & ঢ̆ & $\vec{\triangleright}$ & I & $\underset{\infty}{\vec{\infty}}$ & $\begin{array}{l}\square \\
\sigma\end{array}$ & $\vec{\nabla}$ & $\underset{\infty}{\grave{\infty}}$ & $\vec{u}$ & $\overrightarrow{0}$ & $\vec{\infty}$ & $\begin{array}{l}\vec{\infty} \\
i n\end{array}$ & BLTR \\
\hline$\stackrel{\square}{ \pm}$ & à & $\vec{N}$ & $\vec{a}$ & 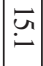 & $\bar{N}$ & प̆ & ज̆ & $\underset{\infty}{+}$ & $\vec{\omega}$ & $\ddot{\infty}$ & $\vec{\omega}$ & $\stackrel{\rightleftarrows}{\forall}$ & $\underset{\infty}{\bar{\infty}}$ & $\vec{~}$ & I & $\vec{F}$ & $\overrightarrow{0}$ & $\stackrel{P}{0}$ & $\vec{t}$ & $\underset{\triangleright}{\vec{A}}$ & $\bar{O}$ & $\vec{~}$ & a & LLTR \\
\hline$\underset{\omega}{\vec{\omega}}$ & 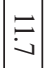 & $\bar{\omega}$ & $\overrightarrow{6}$ & $\mid \begin{array}{l}\overrightarrow{2} \\
\dot{\alpha}\end{array}$ & 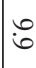 & $\Xi$ & $\stackrel{N}{\omega}$ & 1 & $\stackrel{N}{0}$ & i & $\underset{\infty}{\stackrel{\infty}{\infty}}$ & $\overrightarrow{0}$ & $\stackrel{\bullet}{\sim}$ & : & । & 잉 & $\stackrel{\circ}{0}$ & ํㅡ & 잉 & $\underset{\text { in }}{\overrightarrow{0}}$ & $\begin{array}{l}0 \\
\text { in }\end{array}$ & $\overline{0}$ & $\stackrel{ }{-}$ & BLTA \\
\hline$\Xi$ & $\overrightarrow{\vec{r}}$ & $\begin{array}{l}\bar{N} \\
\dot{u}\end{array}$ & $\begin{array}{l}\overline{\tilde{\omega}} \\
\dot{\omega}\end{array}$ & $\stackrel{\sim}{-}$ & $\stackrel{N}{6}$ & $\vec{\omega}$ & $\bar{a}$ & 1 & $\underset{i}{\omega}$ & $\tilde{\omega}$ & $\stackrel{N}{\sim}$ & ज̆ & $\bar{N}$ & $\underset{\infty}{\bar{\infty}}$ & । & 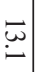 & $\bar{N}$ & $\overrightarrow{0}$ & 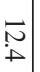 & $\vec{\omega}$ & $\begin{array}{l}\overrightarrow{0} \\
\text { ir }\end{array}$ & $\vec{w}$ & $\vec{N}$ & LLTA \\
\hline $\overrightarrow{6}$ & $\stackrel{\bullet}{\sim}$ & $\begin{array}{l}\infty \\
i \\
i\end{array}$ & $\vec{\square}$ & 1 & $\stackrel{5}{0}$ & $\underset{\perp}{\not}$ & \% & 1 & 1 & $\ddot{0}$ & in & $\overrightarrow{8}$ & $\vec{i}$ & $\stackrel{0}{\sim}$ & । & 잉 & $\stackrel{0}{0}$ & । & $\stackrel{0}{\sim}$ & 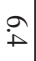 & $\hat{i} \mid$ & $\infty$ & $\overrightarrow{i_{1}}$ & LENC \\
\hline$\because$ & $\mid \begin{array}{l}u \\
+\infty\end{array}$ & $+\vec{a}$ & à & 1 & $\ddot{v}$ & $\ddot{\infty}$ & $\ddot{n}$ & 1 & 1 & $\hat{0}$ & $\stackrel{\infty}{\infty}$ & $\ddot{\sigma}$ & $\stackrel{\omega}{\infty}$ & $\stackrel{+}{\oplus}$ & । & 心) & $\dot{\omega}$ & । & 0 & $\tilde{\omega}$ & in & $\ddot{a}$ & 茫 & LE1C \\
\hline$\ddot{\omega}$ & 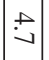 & $\stackrel{\vec{\omega}}{\mathrm{w}}$ & $\stackrel{+}{\infty}$ & $\stackrel{\vec{b}}{+}$ & $\ddot{n}$ & in & $\ddot{0}$ & $\omega$ & in & $\stackrel{H}{i}$ & $\omega$ & $\underset{i}{u}$ & $\stackrel{\omega}{\phi}$ & $\ddot{a}$ & । & $\stackrel{+}{\infty}$ & $\stackrel{+}{\mathrm{i}}$ & $\dot{o}$ & 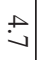 & $\bar{u}$ & $\dot{\omega}_{0}$ & $\tilde{\omega}$ & 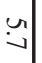 & LE2C \\
\hline$\vec{\nabla}$ & $\left|\begin{array}{l}\infty \\
\dot{\sigma}\end{array}\right|$ & $\overrightarrow{i r}$ & $\vec{\ddots}$ & 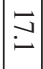 & $\stackrel{2}{0}$ & $\bar{\omega}$ & $\begin{array}{l}\infty \\
i\end{array}$ & $\vec{i}$ & 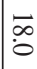 & $\bar{\omega}$ & $\vec{u}$ & $\begin{array}{l}5 \\
0\end{array}$ & प̆ & $\stackrel{\vec{p}}{a}$ & 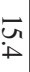 & ă & $\vec{\forall}$ & $\vec{i}$ & $\underset{i}{F}$ & $\vec{v}$ & $\vec{\ddots}$ & $\vec{a}$ & $\begin{array}{c}\vec{\infty} \\
\infty\end{array}$ & WTR \\
\hline$\infty$ & $\left|\begin{array}{l}\infty \\
\dot{\sim}\end{array}\right|$ & $\vec{\nabla}$ & $\stackrel{\nabla}{\sim}$ & $\mid \begin{array}{l}\infty \\
\not \triangleright\end{array}$ & $\ddot{a}$ & $\bar{\omega}$ & जे & 1 & $\mid \begin{array}{l}\infty \\
\alpha\end{array}$ & $\vec{\sim}$ & $\vec{i}$ & $\begin{array}{l}6 \\
0\end{array}$ & $\ddot{v}$ & $\vec{a}$ & $\vec{u}$ & $\overrightarrow{\hat{i}}$ & $\underset{\omega}{\infty}$ & $\overrightarrow{\ddot{r}}$ & $\vec{a}$ & $\overrightarrow{\vec{r}^{\prime}}$ & $\left|\begin{array}{l}\vec{u} \\
\dot{u}\end{array}\right|$ & $\vec{a}$ & $\vec{\infty}$ & WTA \\
\hline $\begin{array}{c}\vec{a} \\
a\end{array}$ & $\overline{\hat{\sigma}}$ & $\begin{array}{l}\bar{u} \\
\sigma\end{array}$ & $\begin{array}{l}\vec{u} \\
\vec{A}\end{array}$ & $\overline{6}$ & $\stackrel{\nexists}{ \pm}$ & $\mid \vec{\omega}$ & $\underset{\infty}{\vec{\infty}}$ & $\vec{a}$ & $\underset{\infty}{2}$ & $\vec{\omega}$ & $\stackrel{\nexists}{ \pm}$ & $\vec{\forall}$ & $\vec{\sigma}^{\omega}$ & $\underset{i}{\vec{N}}$ & $\vec{t}$ & $\overrightarrow{0}$ & $\bar{\sigma}$ & $\vec{\omega}$ & $\overrightarrow{.}$ & $\underset{0}{*}$ & $\begin{array}{l}\overrightarrow{.} \\
0\end{array}$ & $\vec{E}$ & ज्ञ & WCON \\
\hline । & $: 0$ & 1 & । & 1 & I & 1 & $\infty$ & 1 & & $\overbrace{-\infty}^{\infty}$ & 1 & $\stackrel{\infty}{*}$ & । & $i$ & । & । & । & । & $\overrightarrow{6}$ & $\stackrel{\infty}{+}$ & $\vec{a}$ & $\begin{array}{l}\infty \\
i \sim\end{array}$ & । & HE1 \\
\hline 1 & $\stackrel{\infty}{\triangleright}$ & 1 & 1 & । & । & $\stackrel{y}{9}$ & $\infty$ & 1 & 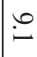 & $\infty$ & 1 & $\stackrel{\infty}{+}$ & । & $\dot{\omega}$ & । & 1 & । & । & $\vec{A}$ & بn & $\left|\begin{array}{ll}u \\
\omega\end{array}\right|$ & $\because$ & । & HGE2 \\
\hline$\vec{u}$ & $\left|\begin{array}{c}\infty \\
\infty\end{array}\right|$ & 1 & 1 & । & 1 & i & in & 1 & 1 & $\infty$ & 1 & 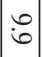 & । & $\stackrel{\infty}{i}$ & । & । & $\underset{\sim}{\infty}$ & । & 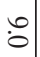 & $\because$ & $\infty$ & $\ddot{\infty}$ & । & DPR-ME \\
\hline $\begin{array}{l}\mathbf{c}_{1} \\
\infty \\
\infty\end{array}$ & $\left|\begin{array}{c}\infty \\
\dot{1} \\
\dot{q}\end{array}\right|$ & $\mid \begin{array}{l}0 \\
\frac{1}{\infty} \\
\infty\end{array}$ & $\mid \begin{array}{c}N \\
\stackrel{N}{\omega} \\
\end{array}$ & & $\stackrel{\odot}{\stackrel{+}{\not}}$ & 검 & 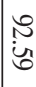 & 1 & 1 & 엉 & $\stackrel{\circlearrowleft}{\ddots}$ & $\begin{array}{l}0 \\
0 \\
\infty \\
\sigma\end{array}$ & $\begin{array}{l}\mathscr{8} \\
\pm \\
\pm\end{array}$ & $\underset{N}{\mathbb{N}}$ & । & $\begin{array}{l}8 \\
\dot{3} \\
\text { in }\end{array}$ & $\begin{array}{l}u \\
\dot{u} \\
.\end{array}$ & 1 & $\begin{array}{l}+ \\
\stackrel{8}{8}\end{array}$ & $\begin{array}{l}\hat{N} \\
\stackrel{0}{o}\end{array}$ & $\begin{array}{l}\infty \\
\infty \\
\dot{0}\end{array}$ & $\stackrel{\vartheta}{\vec{\Xi}}$ & $\begin{array}{l}\text { 혀 } \\
\text { 히 }\end{array}$ & $($ LE2C/LE1C)*100 \\
\hline 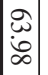 & $\left|\begin{array}{l}1 \\
\infty \\
\infty \\
\infty\end{array}\right|$ & $\mid \begin{array}{l}1 \\
\infty \\
\omega \\
\omega\end{array}$ & $\mid \begin{array}{l}u_{1} \\
0 \\
\dot{f}\end{array}$ & $\begin{array}{l}\mathfrak{N} \\
0 \\
0 \\
0\end{array}$ & 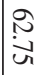 & খু & । & । & $\stackrel{?}{\stackrel{0}{0}}$ & $\begin{array}{l}\vec{y} \\
\vec{g}\end{array}$ & $\begin{array}{l}u \\
\omega \\
\omega\end{array}$ & 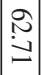 & $\stackrel{\text { oे }}{\omega}$ & ي̆ & । & 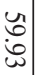 & $\begin{array}{l}u \\
\dot{u} \\
\infty\end{array}$ & $\begin{array}{l}8 \\
8 \\
8\end{array}$ & 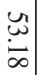 & $\frac{a}{8}$ & $\begin{array}{c}\stackrel{N}{\sim} \\
\infty\end{array}$ & $\begin{array}{l}2 \\
\stackrel{9}{9} \\
0\end{array}$ & $\stackrel{ح}{\Xi}$ & $($ WTR/MAXL)*100 \\
\hline $\begin{array}{l}2 \\
0 \\
0\end{array}$ & $\left|\begin{array}{l}u_{1} \\
\pm \\
\pm\end{array}\right|$ & $\begin{array}{l}2 \\
\infty \\
0\end{array}$ & $\begin{array}{l}6 \\
0 \\
0 \\
0\end{array}$ & $\begin{array}{l}\stackrel{a}{a} \\
\dot{\omega}\end{array}$ & N & 农 & । & । & 它 & $\stackrel{\curvearrowright}{\infty}$ & $\stackrel{\vartheta}{\ddot{\omega}}$ & 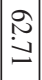 & $\begin{array}{l}\text { 心े } \\
\text { Һ̆ }\end{array}$ & $\begin{array}{l}\text { i } \\
\text { un }\end{array}$ & । & 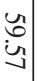 & 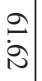 & $\begin{array}{l}u \\
\dot{8} \\
\dot{q}\end{array}$ & 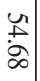 & 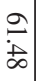 & 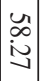 & $\begin{array}{l}\text { oे } \\
0 \\
0\end{array}$ & 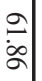 & $($ WTA/MAXL)*100 \\
\hline $\begin{array}{l}\infty \\
0 \\
0 \\
0\end{array}$ & 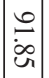 & $\begin{array}{l}0 \\
0 \\
\stackrel{0}{0}\end{array}$ & $\begin{array}{l}\infty \\
0 \\
\omega \\
\omega\end{array}$ & $\begin{array}{l}\text { O } \\
\text { î } \\
\end{array}$ & $\underset{\infty}{\infty}$ & $\begin{array}{l}0 \\
\omega \\
0 \\
-1\end{array}$ & $\underset{\infty}{\risingdotseq}$ & 1 & $\stackrel{0}{\infty}$ & શ & 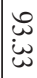 & $\begin{array}{l}8 \\
8 \\
8\end{array}$ & $\begin{array}{l}\text { \& } \\
\text { ü }\end{array}$ & 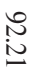 & & 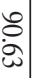 & $\begin{array}{l}0 \\
\stackrel{c}{\infty} \\
\vec{\infty}\end{array}$ & $\begin{array}{l}2 \\
2 \\
\infty \\
+\end{array}$ & \begin{tabular}{l}
2 \\
\multirow{\omega}{\omega}{}
\end{tabular} & $\begin{array}{l}+ \\
\dot{8} \\
\dot{g}\end{array}$ & \begin{tabular}{l}
0 \\
\hdashline \\
\hdashline
\end{tabular} & 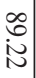 & 点 & RELWCON \\
\hline 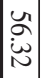 & 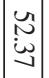 & 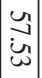 & $\mid \begin{array}{l}1 \\
\infty \\
0 \\
0\end{array}$ & $\mid \begin{array}{l}u \\
u \\
u \\
u \\
u\end{array}$ & $\begin{array}{l}\vec{f} \\
\doteq\end{array}$ & \begin{tabular}{l} 
N \\
\multirow{2}{\sigma}{}
\end{tabular} & بூ & 1 & $\begin{array}{l}u \\
\text { un } \\
\text { un }\end{array}$ & $\mid \begin{array}{l}u \\
\omega \\
\omega \\
\omega\end{array}$ & $\stackrel{u}{\ddot{\partial}}$ & $\begin{array}{l}+ \\
\infty \\
\dot{u}\end{array}$ & 品 & 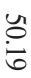 & । & : & $\underset{⿱ 亠 䒑}{ \pm}$ & 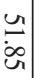 & $\begin{array}{l}u \\
\breve{u} \\
\ddot{u}\end{array}$ & ֵ̆ & $\begin{array}{l}8 \\
0 \\
\dot{u}\end{array}$ & :ă & $\begin{array}{l}. \\
\infty \\
\infty \\
\infty\end{array}$ & $($ LLTR/MAXL)*100 \\
\hline 1 & $\left|\begin{array}{l}0 \\
\vdots \\
\omega \\
-\end{array}\right|$ & 1 & । & 1 & 1 & 1 & $\frac{\%}{ \pm}$ & 1 & 1 & 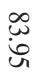 & । & $\begin{array}{l}2 \\
\text { 心 }\end{array}$ & । & $\begin{array}{l}\circ \\
\vdots\end{array}$ & । & । & । & । & $\begin{array}{l}0 \\
\vdots \\
\vdots\end{array}$ & $\begin{array}{l}8 \\
0 \\
0\end{array}$ & $\begin{array}{l}0 \\
\vec{p} \\
\overrightarrow{+}\end{array} \mid$ & $\begin{array}{l}2 \\
\dot{0} \\
\dot{0}\end{array}$ & 1 & $($ HE2/HE1)*100 \\
\hline $\begin{array}{l}0 \\
\infty \\
\infty \\
\infty\end{array}$ & $\left|\begin{array}{l}\infty \\
w \\
\stackrel{1}{N}\end{array}\right|$ & 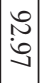 & $\begin{array}{l}0 \\
0 \\
0 \\
i\end{array}$ & 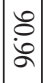 & $\begin{array}{l}\infty \\
\stackrel{\infty}{\sim} \\
\text { un }\end{array}$ & $\stackrel{\infty}{\stackrel{\infty}{ \pm ্ 山}}$ & 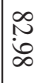 & $\mid \begin{array}{l}\infty \\
u \\
u \\
u\end{array}$ & $\begin{array}{l}\omega \\
\dot{\infty}\end{array}$ & $\begin{array}{l}\infty \\
\infty \\
\sim \\
\sigma\end{array}$ & $\stackrel{\infty}{\stackrel{\infty}{=}}$ & $\mid \begin{array}{c}\sim \\
\dot{\omega} \\
\infty \\
\infty\end{array}$ & 岕 & $\begin{array}{l}\text { ত্ } \\
\text { i্ }\end{array}$ & I & $\stackrel{\infty}{\stackrel{\infty}{a}}$ & $\begin{array}{l}\stackrel{\infty}{\lrcorner} \\
\stackrel{\omega}{\omega}\end{array}$ & 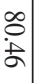 & $\begin{array}{l}\infty \\
\stackrel{\sim}{\sim} \\
\stackrel{\sim}{2}\end{array}$ & 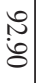 & 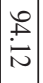 & 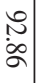 & 呈 & $($ LLTR/BLTR)*100 \\
\hline$\underset{0}{t}$ & $\begin{array}{c}\vec{\omega} \\
\underset{\omega}{\omega}\end{array}$ & 1 & । & I & 1 & 崔 & 岕 & 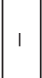 & I & $\frac{f}{g}$ & 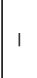 & $\stackrel{\stackrel{u}{\Xi}}{=}$ & 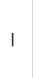 & ֶ̆ & & & $\stackrel{\vec{b}}{\smile}$ & । & $\begin{array}{l}\vec{\omega} \\
\dot{\omega}\end{array}$ & $\begin{array}{l}\overrightarrow{0} \\
\dot{+}\end{array}$ & $\begin{array}{l}1 \\
\infty \\
\dot{0}\end{array}$ & 点 & I & $(\mathrm{DPR}-\mathrm{ME} / \mathrm{WTR}) * 100$ \\
\hline $\begin{array}{l}\stackrel{N}{\infty} \\
\vec{\nabla}\end{array}$ & 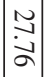 & & 1 & 1 & । & N & 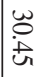 & & I & 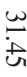 & & 岕 & । & $\frac{\omega}{\sigma}$ & & & 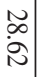 & 1 & 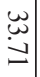 & $\begin{array}{l}\text { ㄴ. } \\
\text { \&̊ }\end{array}$ & 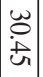 & $\begin{array}{l}\infty \\
\& \\
\&\end{array}$ & । & $(\mathrm{DPR}-\mathrm{ME} / \mathrm{MAXL}) * 100$ \\
\hline
\end{tabular}


Tab. A7. Measurements and indexes for m3.

\begin{tabular}{|c|c|c|c|c|c|c|c|c|}
\hline 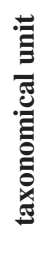 & m3 & $\mathbf{s} / \mathbf{d}$ & $\vec{x}$ & 曾 & $\frac{3}{k}$ & 茨 & $\overleftrightarrow{3}$ & 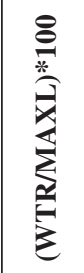 \\
\hline \multirow{19}{*}{$\begin{array}{l}= \\
\mathscr{\Omega} \\
\sum\end{array}$} & $2006 / 10$ & $\mathrm{~d}$ & 26.5 & 15.2 & 18.9 & 18.9 & 16.3 & 71.32 \\
\hline & $2009 / 11$ & $\mathrm{~s}$ & 24.0 & 14.9 & 18.6 & 18.3 & 17.5 & 76.25 \\
\hline & $2009 / 33 b$ & $\mathrm{~s}$ & - & 16.7 & 19.5 & 19.4 & 17.4 & - \\
\hline & $2009 / 34 b$ & $\mathrm{~s}$ & $\mathrm{v}$ & 14.9 & 17.8 & 18.0 & 15.7 & - \\
\hline & $2009 / 35 b$ & $\mathrm{~s}$ & 22.8 & - & 17.7 & 17.4 & 15.9 & 76.32 \\
\hline & $2009 / 36 b$ & $\mathrm{~s}$ & 24.6 & - & 17.8 & 17.8 & 15.8 & 72.36 \\
\hline & $2009 / 37$ & $\mathrm{~d}$ & 25.2 & - & 17.6 & - & - & - \\
\hline & $2009 / 75$ & $\mathrm{~d}$ & 29.4 & 15.7 & 18.6 & 18.1 & 17.0 & 61.56 \\
\hline & $2010 / 5$ & $\mathrm{~s}$ & 24.4 & 12.5 & 20.5 & 19.6 & 19.7 & 80.33 \\
\hline & $2010 / 12 \mathrm{c}$ & $\mathrm{s}$ & 22.8 & 12.4 & 17.0 & 16.6 & 16.4 & 72.81 \\
\hline & $2010 / 13 b$ & $\mathrm{~s}$ & 25.4 & 15.0 & & 19.5 & 18.2 & 76.77 \\
\hline & $2010 / 14$ & $\mathrm{~d}$ & 23.1 & 13.1 & 17.9 & 17.2 & 17.1 & 74.46 \\
\hline & $2012 / 18$ & $\mathrm{~s}$ & - & - & - & - & 17.5 & - \\
\hline & $2012 / 20$ & $\mathrm{~d}$ & 24.4 & 15.5 & 18.8 & 18.8 & 16.3 & 77.05 \\
\hline & $2012 / 21$ & $\mathrm{~s}$ & 26.3 & 18.7 & 20.2 & 19.8 & 18.4 & 75.29 \\
\hline & Ok 139150c & $\mathrm{d}$ & 23.9 & 14.5 & 17.6 & 17.2 & 15.1 & 71.97 \\
\hline & Ok 139174 & $\mathrm{~s}$ & 27.4 & 15.7 & 19.8 & 18.5 & 18.5 & 67.52 \\
\hline & Ok 139176 & $\mathrm{~d}$ & 26.6 & 15.7 & 17.7 & 16.9 & 17.4 & 63.53 \\
\hline & Ok 138971 & $\mathrm{~s}$ & 25.1 & 13.5 & 18.9 & 18.3 & 18.5 & 72.91 \\
\hline \multirow{2}{*}{$\mathrm{CH}$} & $2006 / 1$ & $\mathrm{~s}$ & 21.8 & 13.6 & 17.4 & 17.0 & 13.6 & 77.98 \\
\hline & Ok 139026c & $\mathrm{s}$ & 20.6 & 13.0 & 17.0 & 16.7 & 15.4 & 81.07 \\
\hline
\end{tabular}

